\title{
The flux of organic matter through a peatland ecosystem - the role of cellulose, lignin and their control of the ecosystem oxidation state
}

DOI:

10.1002/2016JG003697

\section{Document Version}

Final published version

Link to publication record in Manchester Research Explorer

Citation for published version (APA):

Worrall, F., Moody, C. S., Clay, G., Burt, T. P., \& Rose, R. (2017). The flux of organic matter through a peatland ecosystem - the role of cellulose, lignin and their control of the ecosystem oxidation state. Journal of Geophysical Research: Biogeosciences. https://doi.org/10.1002/2016JG003697

Published in:

Journal of Geophysical Research: Biogeosciences

\section{Citing this paper}

Please note that where the full-text provided on Manchester Research Explorer is the Author Accepted Manuscript or Proof version this may differ from the final Published version. If citing, it is advised that you check and use the publisher's definitive version.

\section{General rights}

Copyright and moral rights for the publications made accessible in the Research Explorer are retained by the authors and/or other copyright owners and it is a condition of accessing publications that users recognise and abide by the legal requirements associated with these rights.

\section{Takedown policy}

If you believe that this document breaches copyright please refer to the University of Manchester's Takedown Procedures [http://man.ac.uk/04Y6Bo] or contact uml.scholarlycommunications@manchester.ac.uk providing relevant details, so we can investigate your claim.

\section{OPEN ACCESS}




\section{Journal of Geophysical Research: Biogeosciences}

\section{RESEARCH ARTICLE \\ 10.1002/2016JG003697 \\ Key Points: \\ - Processing of organic matter through \\ The flux of organic matter through a peatland ecosystem: The role of cellulose, lignin, and their control of the ecosystem oxidation state} a peatland preferentially removes carbohydrates and retains lignin

- Dissolved organic matter (DOM) from peatlands is derived from processing of lignin and not carbohydrates

- The atmosphere above the peatland experiences an oxidative ratio (OR) less than 1 and not 1.1 as assumed globally

Correspondence to:

F. Worrall,

fred.worrall@dur.ac.uk

Citation:

Worrall, F., C. S. Moody, G. D. Clay, T. P. Burt, and R. Rose (2017), The flux of organic matter through a peatland ecosystem: The role of cellulose, lignin, and their control of the ecosystem oxidation state, J. Geophys. Res. Biogeosci., 122, doi:10.1002/ 2016JG003697.

Received 1 NOV 2016 Accepted 21 MAY 2017 Accepted article online 31 MAY 2017

(C2017. American Geophysical Union. All Rights Reserved.

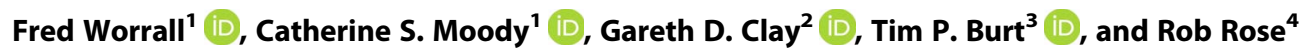 \\ ${ }^{1}$ Department of Earth Sciences, Durham University, Durham, UK, ${ }^{2}$ Geography, School of Environment, Education and \\ Development, University of Manchester, Manchester, UK, ${ }^{3}$ Department of Geography, Durham University, Durham, UK, \\ ${ }^{4}$ Centre for Ecology and Hydrology, Lancaster Environment Centre, Lancaster, UK
}

Abstract This study used thermogravimetric analysis (TGA) to study the transit of organic $C$ through a peatland ecosystem. The biomass, litter, peat soil profile, particulate organic matter (POM), and dissolved organic matter (DOM) fluxes were sampled from the Moor House National Nature Reserve, a peat-covered catchment in northern England where both the dry matter and carbon budget for the catchment were known. The study showed that although TGA traces showed distinct differences between organic matter reservoirs and fluxes, the traces could not readily be associated with particular functionalities or elemental properties. The TGA trace shows that polysaccharides are preferentially removed by humification and degradation with residual peat being dominated by lignin compositions. The DOM is derived from the degradation of lignin while the POM is derived from erosion of the peat profile. The carbon lost as gases $\left(\mathrm{CO}_{2}\right.$ and $\left.\mathrm{CH}_{4}\right)$ was estimated to be composed of 92 to $95 \%$ polysaccharide carbon. The composition of the organic matter lost from the peat ecosystem means that the oxidative ratio (OR) of the ecosystem experienced by the atmosphere was between 0.96 and 0.99: currently, the Intergovernmental Panel on Climate Change uses an OR value of 1.1 for all ecosystems.

\section{Introduction}

Within the terrestrial biosphere, the northern peatlands are the most important terrestrial carbon (C) store. Despite only covering 3\% of Earth's total land area [Rydin and Jeglum, 2013], peatlands store large quantities of carbon. Though estimates vary depending on methods used (see reviews of $Y u$ [2012] and Loisel et al. [2017] for further discussion), it is estimated that $500 \pm 100 \mathrm{GtC}$ is stored in northern peatlands [Gorham, 1991; Yu et al., 2014; Loisel et al., 2014], which is approximately equivalent to the total terrestrial vegetation [(IPCC), 2013], or the cumulative anthropogenic $\mathrm{CO}_{2}$ emissions from fossil fuels, industry, and land use change activities for the period of 1870-2015 [Le Quere et al., 2016].

Many areas of northern peatlands have been subjected to a range of historical and current environmental and anthropogenic pressures, such as climate change, drainage, fire, peat extraction, and land use change. These drivers of change may lead to changes in carbon cycling processes potentially leading to positive feedback mechanisms in turn leading to enhances in atmospheric radiative forcing [e.g., Petrescu et al., 2015].

The very existence of peatlands depends upon the fate of organic matter, and the estimation of $C$ budgets of peatlands has been a common research target. Initial approaches to $C$ budgeting for peatlands were to measure the long-term accumulation rate by dating the depth profile [e.g., Turetsky et al., 2004]. However, this approach must assume accumulation and cannot account for short periods of net loss, nor can it estimate the species of carbon. It is vital to know the species of carbon that are being lost, because carbon from a peatland can be lost to the atmosphere as carbon dioxide $\left(\mathrm{CO}_{2}\right)$ or as the yet more powerful greenhouse gas, methane $\left(\mathrm{CH}_{4}\right)$ [Houghton et al., 1995]. Furthermore, carbon from peatlands can be released into water as dissolved or particulate forms: dissolved organic carbon (DOC) and particulate organic carbon (POC). As an alternative approach, it is possible to consider the carbon budget as the sum of measurements of the ongoing fluxes of all carbon species in and out of the peat ecosystem, and complete contemporary carbon budgets of peatlands are now common [e.g., Worrall et al., 2003; Billett et al., 2004; Roulet et al., 2007; Nilsson et al., 2008]. If carbon is accumulating in peat soils, then the other elements in organic matter must also be accumulating. Contemporary elemental budgets have been extended to include nitrogen (N) 
[e.g., Hemond; 1983; Worrall et al., 2012]. Similarly, Worrall et al. [2016a] considered the transition of organic oxygen (O) through a peat soil ecosystem and showed a peatland to be accumulating oxygen in deep peat soil at a rate of between 16 and $73 \mathrm{tO} \mathrm{km}^{-2} \mathrm{yr}^{-1}$. Long-term accumulation of phosphorus $(P)$ has been measured as 0.69 and $2.04 \mathrm{t} \mathrm{P} / \mathrm{km}^{2} / \mathrm{yr}$ for Chinese peatlands [Wang et al., 2012], between 0.2 and $0.5 \mathrm{t} \mathrm{P} / \mathrm{km}^{2} / \mathrm{yr}$ for a Michigan fen [Richardson and Marshall, 1986], and an average of $1.6 \mathrm{tP} / \mathrm{km}^{2} / \mathrm{yr}$ for Canadian peatlands since the last glaciation [Wang et al., 2015], and Schillereff et al. [2016] have estimated the P accumulation rate for five UK peat bogs and found an average of $18 \pm 4 \mathrm{~kg} \mathrm{P} / \mathrm{km}^{2} / \mathrm{yr}$. Worrall et al. [2016b] found the contemporary P budget of a northern English peat bog to be $+29.4 \mathrm{~kg} \mathrm{P} / \mathrm{km}^{2} / \mathrm{yr}$.

The approaches based on contemporary fluxes do consider the species of the carbon, nitrogen, or oxygen entering or leaving peat ecosystems, and although this can consider the individual gaseous forms (e.g., $\mathrm{N}_{2} \mathrm{O}, \mathrm{CO}_{2}$, or $\mathrm{CH}_{4}$ ), certain carbon fluxes are not considered in any more detail than the lumped terms such as DOC or POC without further characterization. The contemporary budgets consider different types of peatland with different dominant vegetation types, and as such, different substrates. Alternatively, physical and land management controls on carbon biogeochemistry have been considered, for example, the impact on the carbon budget due to drainage [e.g., Rowson et al., 2010]. The impact of land use management and land use change often reflect an influence of water table on the decomposition processes in the peat profile [e.g., Clay et al., 2010]. However, even these detailed studies deal in lumped compositions. For example, primary productivity is viewed as sequestering $\mathrm{CO}_{2}$ from the atmosphere but, of course, it sequesters it to glucose which is then transformed through metabolic cycles and combined with nutrients to build the components of plants-lignin, carbohydrates (cellulose and hemicellulose), proteins, and lipids [McDermitt and Loomis, 1981]. It is this organic matter that is transformed back to $\mathrm{CO}_{2}$ through root respiration, falls as litter, or is released as plant exudates into the soil pores. It is the litter or exudates that then transform to soil organic matter, and this transformation may result in $\mathrm{CO}_{2}, \mathrm{CH}_{4}, \mathrm{DOC}$, or POC. Contemporary carbon budgets have advanced our understanding of processes and drivers and quantified gas, particulate, and dissolved fluxes. The purpose of this paper is to consider the molecular changes occurring as organic matter moves through the peatland ecosystem.

The composition of organic macromolecules that would be present in peatland ecosystems (e.g., lignin) has been considered by a number of approaches: colorimetric methods from UV/vis spectroscopy [e.g., Blackford and Chambers, 1993], coal petrology techniques such as rock-eval [e.g., Carrie et al., 2012], elemental ratios (e.g., C/N [Kuhry and Vitt, 1996]), stable isotopes [e.g., Jones et al., 2010], Fourier transform infrared spectroscopy [e.g., Artz et al., 2008], and pyrolysis gas chromatography-mass spectrometry [e.g., Buurman et al., 2006]. These approaches have commonly be focused upon characterization of peat profiles for the purpose of understanding humification [e.g., Zaccone et al., 2008] or palaeohistoric reconstructions [e.g., McClymont et al., 2011]. None of the above techniques have been used to understand the carbon budget of a peatland.

Thermogravimetric analysis (TGA) has a number of advantages over other techniques for analyzing organic matter composition. First, unlike, for example, biomarkers (e.g., sphagnum acid [Rudolph and Samlund, 1985]), the TGA trace is a measure of the whole sample composition and is not selective; nor does it require extraction or treatment prior to analysis. Second, it is now possible to run the analysis on samples of up to $400 \mathrm{mg}$ which partly avoids issues of heterogeneity of organic matter. Thermogravimetric analysis has been used to characterize soil organic matter (SOM) [e.g., Lopez-Capel et al., 2005; Plante et al., 2009], and it can be viewed as the more generic version of rock-eval [Gregorich et al., 2015]. These studies have generally considered soil organic matter and have focused on the issue of whether thermal stability, as measured by thermogravimetric techniques, can be related to biological stability of SOM in the environment [e.g., Plante et al., 2011], but the technique has not been used to analyze flows of organic matter through an environment. Therefore, the purpose of this study was to use TGA to trace organic matter compositional changes from a site where the carbon budget is already well constrained.

\section{Approach and Methodology}

The approach taken here was to analyze the composition of the organic matter in a series of carbon pools within the context of a known carbon budget (Figure 1). The composition was analyzed using thermogravimetry, elemental analysis (for $\mathrm{C}, \mathrm{H}, \mathrm{N}$, and $\mathrm{O}$ ), and ${ }^{13} \mathrm{C}$ solid state nuclear magnetic resonance (NMR). The 


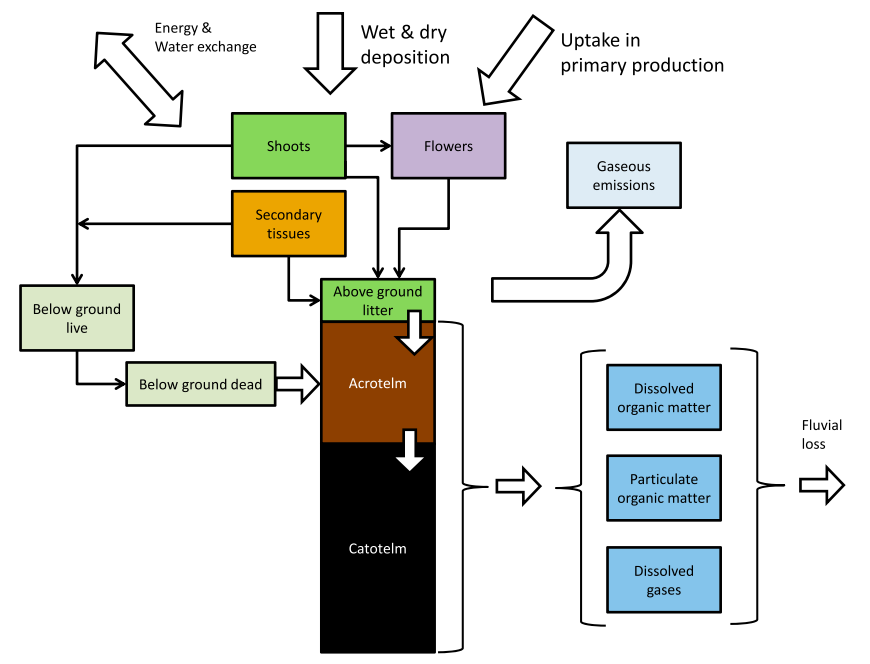

Figure 1. Schematic diagram of organic matter pools and fluxes considered by this study. the Trout Beck catchment relevant to this study [Sykes and Lane, 1996]. The Trout Beck catchment lies largely above $500 \mathrm{~m}$ asl (above sea level); the highest point is the summit of Great Dun Fell at $848 \mathrm{~m}$ asl. The underlying geology is a succession of Carboniferous limestones, sands, and shales with intrusions of the doleritic Whin Sill [Johnson and Dunham, 1963]. This solid geology is covered by glacial till whose poor drainage facilitated the development of blanket peat during the Holocene. Blanket peat covers $90 \%$ of Trout Beck catchment [Evans et al., 1999]. The recent climate of the site has been summarized by Holden and Rose [2011]: between 1991 and 2006 the mean annual temperature was $5.8^{\circ} \mathrm{C}$, air frosts were recorded on 99 days in a year, and the mean number of days with snow cover was 41 while for the same period the mean annual precipitation was $2012 \mathrm{~mm}$. The vegetation is dominated by Eriophorum sp. (cotton grass), Calluna vulgaris (heather), and Sphagnum sp. (moss).

\subsection{Sampling}

Given the range of carbon pools and fluxes identified in Figure 1, the following sampling was carried out. First, the peat profile was sampled. A location in active, deep peat within the Cottage Hill Sike catchment was selected and a core taken to $1 \mathrm{~m}$ depth with a gouge auger. The depth was selected to ensure coverage of both the acrotelm and catotelm [Worrall et al., 2012]. The peat core was sampled in $2 \mathrm{~cm}$ depth increments

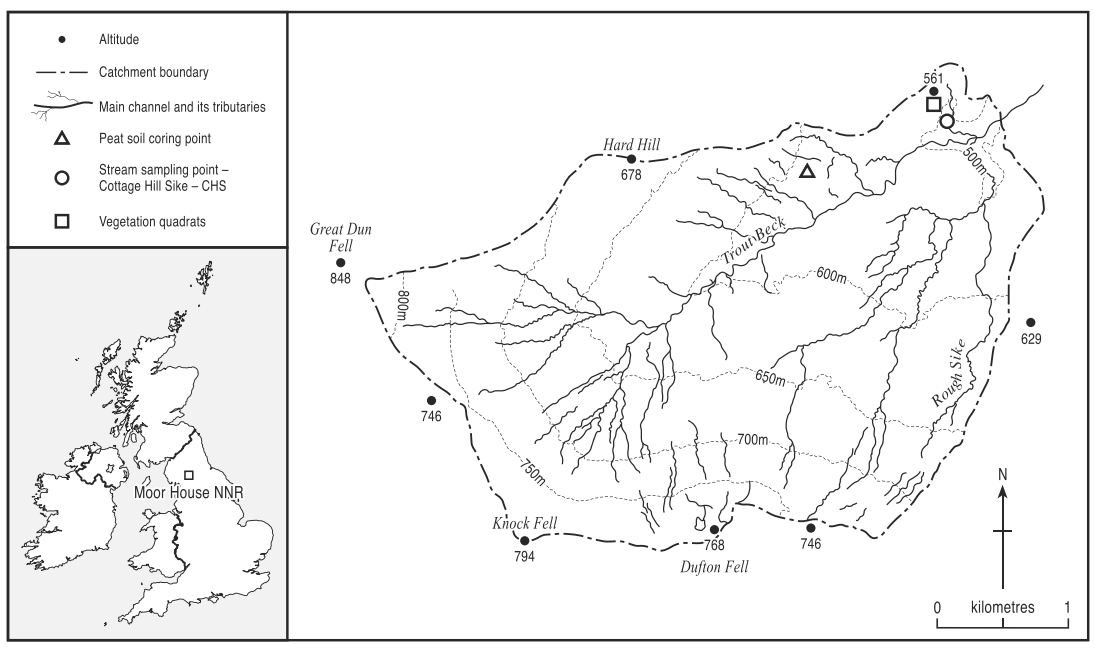

Figure 2. Location of the study site used in this study. 
from 0 to $20 \mathrm{~cm}$ depth from the peat surface, then $5 \mathrm{~cm}$ depth increments from $20 \mathrm{~cm}$ depth to $50 \mathrm{~cm}$, and finally one sample taken between 95 and $100 \mathrm{~cm}$ depth. Peat core samples were dried at $105^{\circ} \mathrm{C}$ overnight and checked for no further mass loss, and their bulk density measured prior to further processing.

Vegetation samples were collected from six quadrats. The six quadrats $\left(0.25 \mathrm{~m}^{2}, 0.5 \times 0.5 \mathrm{~m}\right)$ were located in the Cottage Hill Sike catchment and chosen to cover the three main plant functional groups-shrubs (dominantly Calluna vulgaris, henceforward referred to as Calluna), grasses and sedges (dominantly Eriophorum spp., henceforward referred to as grass/sedge), and mosses (including Sphagnum spp., henceforward referred to as mosses). In three of the quadrats, the entire aboveground biomass was quantitatively recovered. For the three other quadrats, the total aboveground biomass was collected but separated by functional group. From within these quadrats, samples of litter and belowground biomass were recovered but not quantitatively. Quantitative biomass samples were dried to $105^{\circ} \mathrm{C}$ and weighed so that an estimate of total aboveground biomass, and the contribution from the dominant functional plant groups, could be estimated. This estimate was then used to confirm the dry matter budget reported by Forrest [1971]. Forrest [1971] found total aboveground biomass to be $1996 \mathrm{~g} / \mathrm{m}^{2}$ (as dry matter) composing of $78 \%$ Calluna vulgaris, $17 \%$ Eriophorum spp., and 5\% Sphagnum spp. The belowground biomass was $133 \mathrm{~g} / \mathrm{m}^{2}$, and the litter was $590 \mathrm{~g} / \mathrm{m}^{2}$. Samples of the litter and belowground biomass were not recovered quantitatively and were dried to $105^{\circ} \mathrm{C}$. The dried samples were then homogenized and powdered as described below. In this way we were able to consider bulk measures of the vegetation carbon pool (aboveground and belowground biomass) and assess the contribution of its components (plant functional types-Calluna, grasses/sedge, and mosses). It would be expected that the aboveground biomass would be weighted average of its components.

Dissolved organic matter (DOM) samples were taken from Cottage Hill Sike. Large-volume water samples (at least $25 \mathrm{~L}$ ) were collected monthly from October 2011 to December 2014, except for months where winter conditions precluded taking flowing water samples (35 samples taken in total). On return of these samples to the laboratory, the samples were allowed to settle, and the next day the water tapped off from above the sediment layer and evaporated to dryness (between 60 and $80^{\circ} \mathrm{C}$ ) to collect the total dissolved solids. By using settling as means of separation, no filtration cutoff was being applied; rather this study was defining DOM as being that component which was either colloidal or truly dissolved.

From June 2013 to December 2014 the settled sediment was recovered as a sample of the particulate organic matter (POM). The settled sediment was dried to $105^{\circ} \mathrm{C}$ (overnight and checked for no further mass loss) and retained for subsequent analysis.

Finally, four standard materials were included in the analysis: lignin (Aldrich, CAS 8068-05-1), humic acid (Alfa-Aesar, CAS 1415-93-6), cellulose (Whatman, CAS 9004-36-4), and protein (Sigma, CAS 100684-25-1). The lignin, cellulose (taken as representative of polysaccharides, including hemicellulose), and protein present the three largest components of plants found in a peatland system [McDermitt and Loomis, 1981].

The considerable advantage of considering peatland ecosystems is that soil, total dissolved solids, and suspended sediment would be expected to be predominantly organic matter, but nevertheless the ash content of the samples was analyzed. A subsample of the biomass, litter, peat, DOM, and POM collected was ashed at $550^{\circ} \mathrm{C}$, and the residual mass was recorded. All subsequent analyses of peat, DOM, and POM were corrected so that all elemental analyses are quoted on an ash-free basis.

\subsection{Elemental Analysis}

Triplicate samples of all the collected samples (aboveground and belowground vegetation, litter, peat soil, $\mathrm{DOM}$, and $\mathrm{POM}$ ) once dried to $105^{\circ} \mathrm{C}$ were then milled to a submillimeter powder using a Spex 6770 Freezer Mill. For the samples of DOM and POM cyromilling was not necessary. The ground samples were then subject to carbon, hydrogen nitrogen (CHN), and separately to oxygen (O) analysis on a Costech ECS 4010 Elemental combustion system with pneumatic autosampler. Computer software used was EAS Clarity (DataApex Ltd, Prague, Czech Republic). For both CHN setup and the separate O setup, calibration curves of $r^{2}>0.999$ were created using acetanilide as the standard. Samples of acetanilide were included within each run as unknown samples to act as internal quality control checks. Each sample was analyzed in triplicate, i.e., three times on the $\mathrm{CHN}$ setup and a further three times on $\mathrm{O}$ setup, and a mean was calculated for $\mathrm{C}, \mathrm{H}, \mathrm{N}$, and $\mathrm{O}$. All samples were corrected for their measured ash content. 
Table 1. The Ranges of Chemical Shifts for ${ }^{13} \mathrm{C}$ NMR, From Chadwick et al. [2004]

Chemical Shift (ppm)

$0-45$

45-65

65-95

95-110

110-145

$145-160$

160-190

$190-220$ phenolic- $C$
Types of Carbon

C-alkyl

$\mathrm{N}$-alkyl/methoxyl-C

O-alkyl

$\mathrm{O}_{2}$-alkyl/acetal C

aromatic/unsaturated-C

amide/carboxyl-C

aldehyde/ketone-C
The elemental analysis results were converted to molar percentage and considered as elemental ratios but also as measures of oxidation state ( $C_{\text {ox }}$ and OR [Masiello et al., 2008]) and the degree of unsaturation $(\Omega$ [McMurray, 2004]).

$$
C_{o x}=\frac{2[\mathrm{O}]-[\mathrm{H}]+3[\mathrm{~N}]}{[\mathrm{C}]}
$$

where $[X]$ indicates molar concentration of $\mathrm{C}, \mathrm{H}, \mathrm{N}$, or $\mathrm{O}$. The $\mathrm{OR}$ value is then calculated as

$$
\mathrm{OR}=1-\frac{\mathrm{Cox}_{\mathrm{ox}}}{4}+\frac{3[\mathrm{~N}]}{4[\mathrm{C}]}
$$

and the degree of unsaturation $(\Omega)$ is defined as

$$
\Omega=[\mathrm{C}]-\frac{[\mathrm{H}]}{2}+\frac{[\mathrm{N}]}{2}+1
$$

The value of $C_{\mathrm{ox}}$ can be related to the nominal oxidation of the carbon as developed by LaRowe and Van Cappellan [2011]. As noted by Gallagher et al. [2014], OR is not only a property of organic matter (e.g., peat soil) but can also be a property of an ecosystem and its biosphere-atmosphere exchanges. The OR is defined as the ratio of moles of oxygen $\left(\mathrm{O}_{2}\right)$ produced per mole carbon dioxide $\left(\mathrm{CO}_{2}\right)$ sequestered by the terrestrial biosphere, and the OR has been used to refine estimates of terrestrial and oceanic carbon sinks of fossil fuel emissions [Keeling et al., 1996; Prentice et al., 2001]. The OR and Cox are linearly related [Masiello et al., 2008].

2.4. ${ }^{13} \mathrm{C}$ Solid-State Nuclear Magnetic Resonance $\left({ }^{13} \mathrm{C}-\mathrm{NMR}\right)$

The ${ }^{13} \mathrm{C}$ solid-state NMR data were obtained at the EPSRC UK National Solid-state NMR Service at Durham University. Solid-state ${ }^{13} \mathrm{C}$ spectra were recorded at $100.56 \mathrm{MHz}$ using a Varian VNMRS spectrometer and a $4 \mathrm{~mm}$ magic-angle spinning probe. They were obtained using cross polarization with a $0.5 \mathrm{~s}$ recycle delay, $1 \mathrm{~ms}$ contact time, at ambient probe temperature $\left(\sim 25^{\circ} \mathrm{C}\right)$ and at a sample spin-rate of $14 \mathrm{kHz}$. Between 50,000 and 100,000 repetitions were accumulated. The pulse sequence is a Durham-modified version of a generic provided by the manufacturer. The pulse sequence was a direct excitation one with "DEPTH" background suppression and high-power spinal-64 proton decoupling. Radiofrequency fields equivalent to $75 \mathrm{kHz}$ were used on both channels. The free induction decay was zero filled to $16 \mathrm{k}$ data points and transformed with $200 \mathrm{~Hz}$ of exponential line broadening. The phased spectrum was baseline corrected using the Bruker "abs" correction with a polynomial of degree 5. Spectral referencing was with respect to an external sample of neat tetramethylsilane (carried out by setting the high-frequency signal from adamantane to $38.5 \mathrm{ppm}$ ). Between 50 and $60 \mathrm{mg}$ of each sample was used. The chemical shift ranges used were adapted from Chadwick et al. [2004] and are shown in Table 1. The maximum peak height in each range was divided by the molar carbon concentration of the sample (from the elemental analysis) to get a relative peak height for each type of carbon observed. All collected samples were analyzed by NMR, and no subset was used.

\subsection{Thermogravimetric Analysis (TGA)}

Thermogravimetric traces were recorded on an SGA I TGH 1200. This analyzer has the advantage that it is a high mass analyzer, and between 300 and $400 \mathrm{mg}$ of organic matter and standard samples could be analyzed at a time. The samples were run from ambient to $1000^{\circ} \mathrm{C}$ at a ramp rate of $10 \mathrm{~K} \mathrm{~min}^{-1}$ within a stream of $\mathrm{N}_{2}$.

The thermogravimetric trace were adjusted to be on a common temperature scale and trimmed to the range 150 to $700^{\circ} \mathrm{C}$ so that any influence from inorganic carbon or absorbed water was excluded. Traces were then normalized to the mass loss between 150 and $700^{\circ} \mathrm{C}$ so that all traces were then on the same scale, i.e., percentage of organic mass loss per $\mathrm{K}$, given the assumption that it is only organic matter lost between 150 and $700^{\circ} \mathrm{C}$. There have been many indices given for TGA traces of soil organic matter with most focused on defining exothermic peaks, but as Plante et al. [2009] have shown, these definitions vary considerably between studies. More importantly with respect to this study, previous studies have focused on a single type of natural 
organic matter, i.e., soil organic matter, but this study considers across the range of natural organic matter in a single environment. Alternatively, this study used the approach of Dell'Abte et al. [2002] who interpreted their results as percentage mass losses summed into $50 \mathrm{~K}$ ranges $\left(150\right.$ to $200^{\circ} \mathrm{C}, 200$ to $250^{\circ} \mathrm{C}$, and so on to 650 to $700^{\circ} \mathrm{C}$ ), and in this manner a single trace of 550 data points is summarized into 10 variables. In addition, the temperature of maximum mass loss was recorded for each trace.

\subsection{Statistical Analysis}

When summarized into $50 \mathrm{~K}$ ranges the data set can be treated as a multivariate data set. Principal component analysis (PCA) was used to assess the differences between organic matter pools and fluxes on the basis of thermal decomposition. Included in this analysis were traces for standards. In the analysis, the components with an eigenvalue $>1$ were considered for further examination, as these components are those which represent more of the data set variance than any of the original variables [Chatfield and Collins, 1980].

The PCA helped assess what compositions were most likely correlated with mass loss within which ranges in the TGA trace, but to test this further stepwise multiple regression was used. The percentage mass loss in each of the ten $50 \mathrm{~K}$ range was compared to (1) parameters derived from the elemental analysis and (2) the proportions of the functionalities as derived from ${ }^{13} \mathrm{C}$ NMR. The stepwise multiple regression was performed using both forward and backward selection with a probability of not being zero $<0.05$ for inclusion.

\subsection{Carbon and Dry Matter Budget}

This study considers organic matter in the ecosystem as transferring through a series of carbon pools and fluxes (Figure 1). The fluxes of gases $\left(\mathrm{N}_{2} \mathrm{O}, \mathrm{CO}_{2}\right.$, and $\left.\mathrm{CH}_{4}\right)$ have fixed and known molecular composition and as such were not analyzed as part of this study.

The dry matter budget of the catchment was first recorded by Forrest [1971] who studied the productive ecology of the dominant species present in the catchment. Forrest [1971] did include biomass production (both aboveground and belowground production) and divided production estimates between the dominant functional plants types within the catchment (Calluna, grass/sedge, and mosses). Forrest [1971] did include litter production rates but not their subsequent decay and peat formation rates nor the loss of production via fluvial pathways. Therefore, this study will combine the study of dry matter production with a carbon budget. This study used the most up-to-date and longest carbon budget information for the site based upon the approach of Worrall et al. [2009, 2012], which summarized the median carbon budget after 13 years of budget information as

$$
100 C_{p p} \Rightarrow 35 C_{R}+26 C_{D O C}+4 C_{C H 4}+4 C_{\text {dissco2 }}+9 C_{P O C}+22 C_{R E S}
$$

where $C_{x}$ indicates the carbon from the following uptake or release pathways, where $x$ representing $p p$ as primary productivity, $\mathrm{R}$ as net ecosystem respiration, $\mathrm{DOC}$ as dissolved organic carbon, $\mathrm{CH} 4$ as methane, disscO2 as dissolved $\mathrm{CO}_{2}, \mathrm{POC}$ as particulate organic carbon, and RES as residual carbon stored in the soil.

The total carbon budget of this ecosystem varied between -20 and $-91 \mathrm{tC} \mathrm{km}^{-2} \mathrm{yr}^{-1}$; i.e., the ecosystem was accumulating carbon from the atmosphere. Equation (4) gives the carbon budget normalized for $100 \mathrm{C}$ atoms taken up by net primary productivity-average net primary productivity across the study period was $-176 \mathrm{t} \mathrm{C} \mathrm{km}^{-2} \mathrm{yr}^{-1}$. The budget status is assessed relative to the atmosphere and thus a sink into the soil is negative. The TGA traces were weighted according to the carbon budget (equation (4)); e.g., the TGA trace of the average biomass was weighted by a factor of 1 (the proportion of primary productivity $C$ in equation (4)) as it represents the primary production and the TGA trace for DOM, weighted by a factor of 0.26 (the proportion of DOM c IN equation (4)), was subtracted from it and this was then performed for each of the carbon species in the budget as presented by equation (4) for which a TGA trace could be measured. The average biomass was calculated as the mix of the TGA traces of the vegetation samples in the above and belowground biomass mixed in the appropriate ratios as defined by Forrest [1971]: this then gives a TGA trace of the primary productivity. The two species of carbon for which there was no trace were the $\mathrm{CO}_{2}\left(\mathrm{C}_{R}+\mathrm{C}_{\text {dissCO2 }}\right.$; equation (4)) and $\mathrm{CH}_{4}$; therefore, the trace of the primary production once all other species have been subtracted from it represents the TGA trace of the organic matter that is transformed to and lost in the gaseous form. In this way it was possible to assess the changes between the organic matter compositions as the organic matter transfers through the ecosystem and so identify what composition has been lost in the process of humification to deep peat soil, degradation to gases, and the creation of fluvial organic matter. 


\section{Results}

The TGA trace for the standards shows that cellulose has two sharp peaks with mass loss focused into these peaks without much mass loss before $270^{\circ} \mathrm{C}$ or after $400^{\circ} \mathrm{C}$ (Figure 3a). In comparison, loss for lignin is more distributed across a wider range of temperatures with peak mass loss higher than that for the cellulose. In contrast, the maximum loss for protein is below that of both cellulose and lignin, but with a considerable proportion of mass loss above $470^{\circ} \mathrm{C}$ which we consider to be combustion of the product of the re-arrangement from the lower temperature mass loss. Humic acid was included but proved to be an erratic trace perhaps reflecting the specific origin of the standard and that it was a mixture of a smaller number of quite distinct molecular compositions as opposed to a more continuous range of compositions.

Both the biomass and litter samples show three peaks (Figure $3 \mathrm{~b}$ ). The low-temperature peak is at $288^{\circ} \mathrm{C}$ in litter and $316^{\circ} \mathrm{C}$ in the biomass which is closest to the position of protein (Figure 3a). Depending upon which study is used for indices, this peak could be exotherm 1 [e.g., Dell'Abte et al., 2003] or exotherm 2 [Kristensen, 1990; Plante et al., 2005]. The second peak with rising temperature and the highest peak for each material are at $348^{\circ} \mathrm{C}$ and $358^{\circ} \mathrm{C}$ for litter and biomass, respectively, and is closest to the cellulose standard; again, this could be compared with exotherms 1 or 2 depending upon the study used for comparison [e.g., LopezCapel et al., 2006]. There is a third peak present in both litter and biomass between $421^{\circ} \mathrm{C}$ and $525^{\circ} \mathrm{C}$ which is not apparent in the standards but would be in the region of exotherm 3 [Lopez-Capel et al., 2006]. Comparing the TGA for the aboveground biomass to that of the individual plant functional groups shows that the best fit (by least squares errors) gave an aboveground biomass composition of $74 \%$ Calluna, $16 \%$ grass/sedge, and $9 \%$ mosses with a mean average percentage error of $0.6 \%$ of mass loss $/ \mathrm{K}$ - within the 95\% confidence interval of values quoted by Forrest [1971].

The peat samples are dominated by a peak at $301^{\circ} \mathrm{C}$ and then a shoulder between 380 and $420^{\circ} \mathrm{C}$ (Figure $3 \mathrm{C}$ ). Examining the change with depth in the peat profile shows that the maximum change between surface and the depth in the peat profile occurred at $356^{\circ} \mathrm{C}$ which is close to peak loss in both cellulose and lignin (Figure 3a). Taking the change at $356^{\circ} \mathrm{C}$ with depth (Figure 4) shows that any change in the peak at $356^{\circ} \mathrm{C}$ is not monotonic but that the change appears to be greatest at $20 \mathrm{~cm}$ depth before decreasing and stabilizing and becoming near-constant after $40 \mathrm{~cm}$ depth, although no samples were taken between 50 and $95 \mathrm{~cm}$ depths. It is possible to consider these changes to relate to position of the water table and the acrotelmcatotelm boundary. Worrall et al. [2012] suggested, on the basis of the $\mathrm{C} / \mathrm{N}$ ratio, that the acrotelm-catotelm boundary was at $42 \mathrm{~cm}$ depth; however, there was no such evidence in the oxidation state of the organic matter [Worrall et al., 2016a]. The oxidation state instead could be reflecting changes in inputs to the peat profile as vegetation and climate shifts on timescales of hundreds of years.

The TGA traces from the POM shows a high degree of commonality with both the peat soil samples and vegetation or litter (Figure 5), but contrasts with the results for the traces for DOM. The TGA traces for DOM show maximum losses at temperatures lower than observed for the other types of organic matter considered (Figure 6).

\subsection{Multiple Regression Analysis}

The median composition of sampled organic matter pools is given in Table 2. Although this study found a number of significant relationships between mass loss and the other compositional measures (Table 3), there were a number of temperature ranges for which no significant relationship with other compositional measures was found including 250 to $300^{\circ} \mathrm{C}$ and between 500 and $600^{\circ} \mathrm{C}$. Equally, there was no significant relationship found between any of the $50 \mathrm{~K}$ ranges and C-alkyl functionality (Table 3). Mass loss in the lowtemperature regions ( 150 to $200^{\circ} \mathrm{C}$ and 200 to $250^{\circ} \mathrm{C}$ ) correlates well with measures of oxidation and oxygen content of the organic matter ( $C_{\mathrm{ox}}$, aldehyde and carbonyl), and indeed increased mass loss in region of 200 to $250^{\circ} \mathrm{C}$ is also correlated with decreasing $\mathrm{H} / \mathrm{C}$ (Table 3). Most of the significant regressions are in the temperature ranges between 300 and $500^{\circ} \mathrm{C}$ which makes it difficult in distinguishing contributions relative to other composition measures-it is this region (i.e., 300 to $500^{\circ} \mathrm{C}$ ) in which the most variation was observed in the TGA traces.

\subsection{Principal Component Analysis}

The analysis of the data set based only on changes in mass in the $50 \mathrm{~K}$ ranges found four components with an eigenvalue $>1$ and together these explain $79 \%$ of the original variance. The first principal component has high negative loadings for mass loss between $300-350^{\circ} \mathrm{C}$ and $350-400^{\circ} \mathrm{C}$ with negative loadings for ranges between 
a

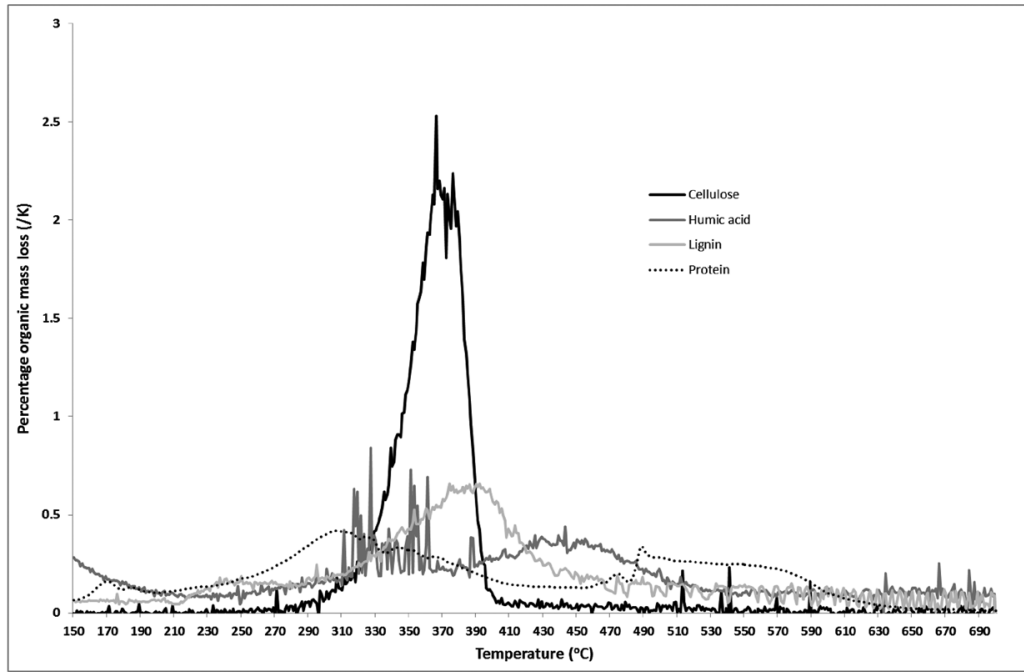

b

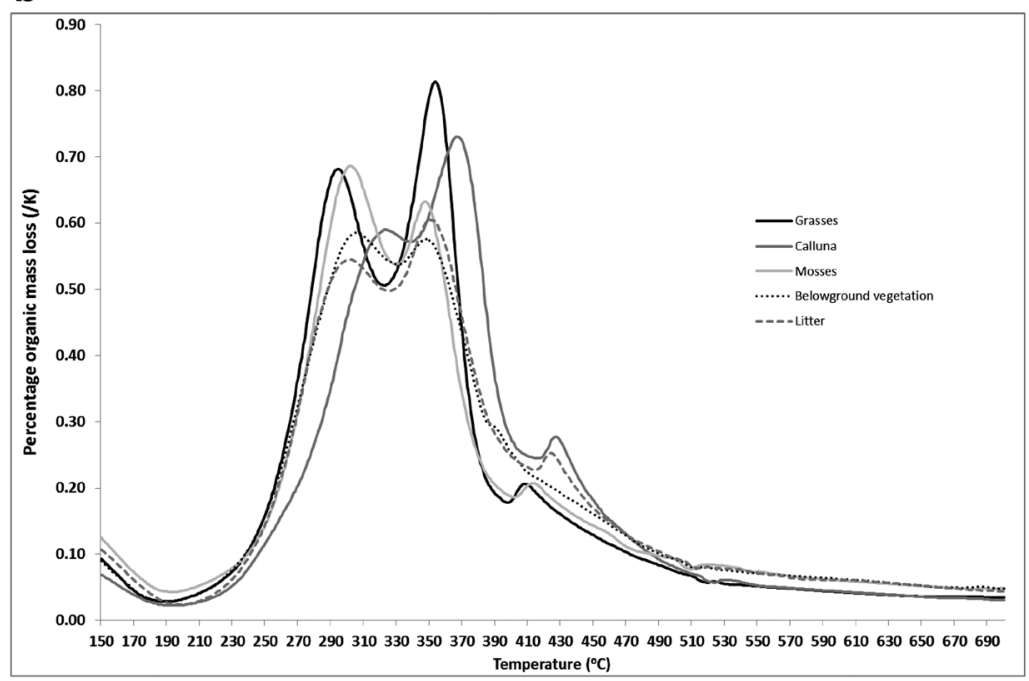

C

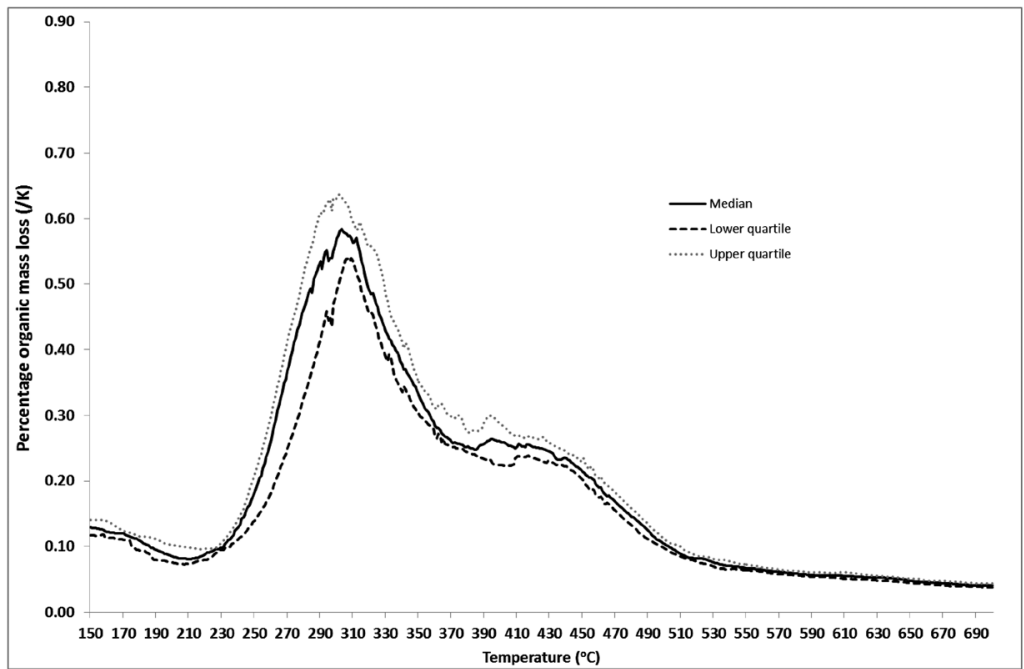

Figure 3. The organic matter normalized TGA trace for (a) standard materials of lignin, cellulose, protein, and humic acid; (b) average biomass and litter; and (c) average peat soil. 


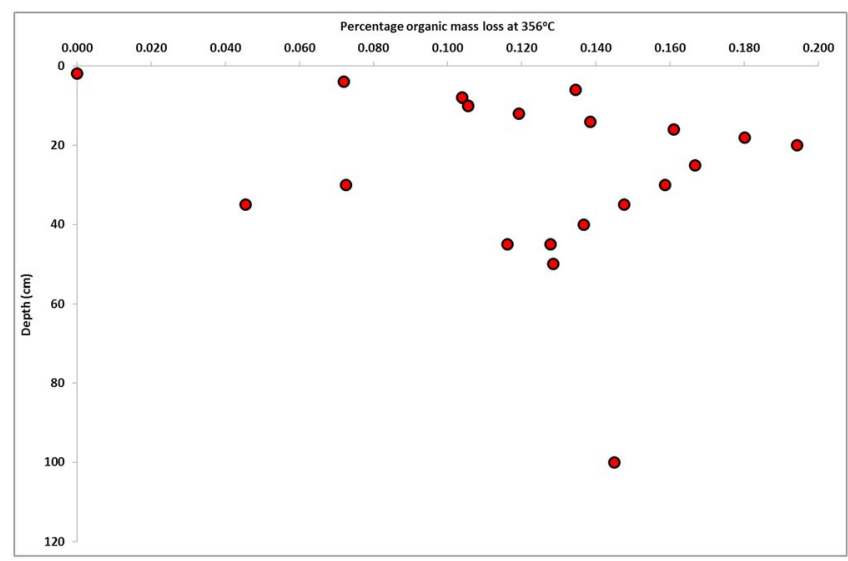

Figure 4. The variation in organic mass loss at $356^{\circ} \mathrm{C}$ with depth in the peat profile.

which implies that cellulose is marked by mass loss peaks in the region 300 to $400^{\circ} \mathrm{C}$. The humic acid standard plots at high positive values of PC2 which means that it is distinguished by mass loss in the ranges 300 to $350^{\circ} \mathrm{C}$ and 450 to $550^{\circ} \mathrm{C}$. The plot of the humic acid standard sets it clearly apart and so is not probably representative of soil humic compounds but rather reflects its particular origin or extraction. Lignin is not distinguished by PC1 but has a positive score on PC2, while protein has positive scores on PC1 which correlates with mass loss in the lower temperature ranges $\left(200\right.$ to $\left.300^{\circ} \mathrm{C}\right)$.

The sample data can be broadly analyzed as plotting in two regions (Figure 7). First, the vegetation, litter, peat, and most of the POM samples plot from between the line joining cellulose and lignin standards and a POM sample (marked A, Figure 7). Peat soil samples plot parallel to the $y$ axis suggesting variation only on PC2. When plotted against the depth (in $\mathrm{cm}$ ) of the sample a clear and significant trend is observed $(\mathrm{PC} 2=0.05+0.029$ depth, $\left.r^{2}=0.39, n=19, P<0.05\right)$ that shows that the shallowest samples plot at the lowest values of PC2 and so are distinguished by mass loss in the $250-300^{\circ} \mathrm{C}$ range. This increase of $P C 2$ with depth suggests that peat evolves toward more lignin-like compositions with depth which represents a shift from mass loss in the 250$300^{\circ} \mathrm{C}$ range to mass loss in the 400 to $450^{\circ} \mathrm{C}$ range. The very shallowest peats soils samples (labeled B) plot very close to some litter samples, while litter and vegetation samples plot between the very shallowest peat soil samples and a line between the cellulose and lignin standards. The vegetation and litter samples can now be interpreted as a mixture of the cellulose, lignin, and protein standards and compared to the composition based upon the elemental analysis (Table 5).

It is possible therefore that POM composition A does not relate to peat, vegetation, and litter samples but instead represents a separate composition. Some POM samples plot with the peat soil samples, and these

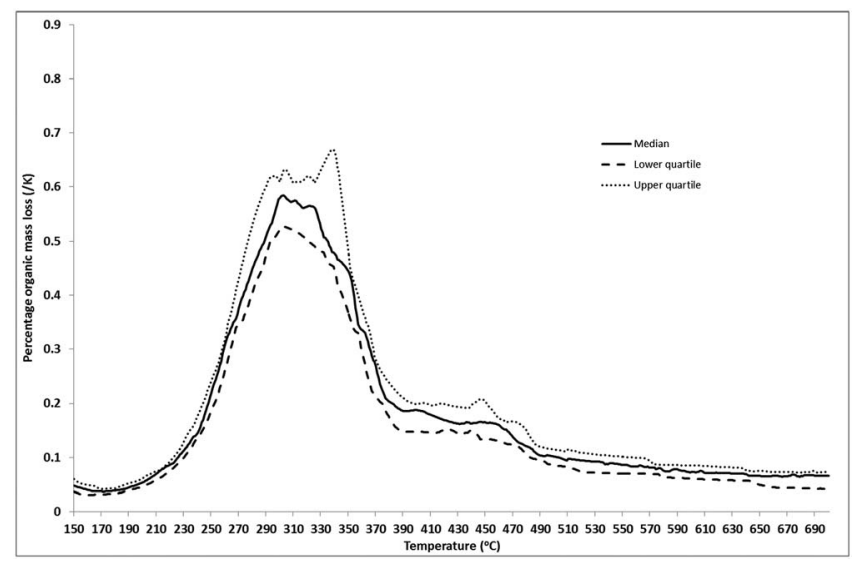

Figure 5. The organic matter normalized TGA trace for average particulate organic matter (POM). can be explained as coming from erosion of the deep peat soils where they are exposed in river banks within the catchment. Alternatively, some POM samples plot close to vegetation and litter implying that in some cases particulate flux is from the peat surface. Worrall et al. [2016a] showed, on the basis of CHNO composition, that POM in this composition was a mixture of vegetation and peat soil. The POM composition A comes from August 2014 whose TGA trace is distinguished by a peak in the range between 200 and $250^{\circ} \mathrm{C}$ and another one in the range between 400 and $450^{\circ} \mathrm{C}$; this could 


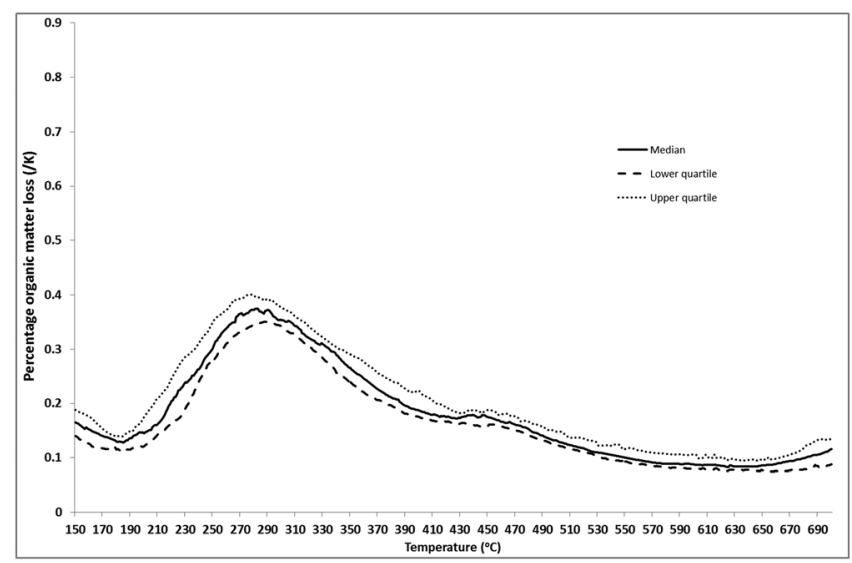

Figure 6. The organic matter normalized TGA trace for average dissolved organic matter (DOM). be autochthonous POM, i.e., a POM sourced from within the stream itself. Alternatively, POM composition A could be viewed as one end-member of a trend that evolves, with both increasing values of both PC2 and PC1, toward and including the DOM samples. Therefore, the POM of composition A could be a flocculated DOM.

All the DOM samples are clearly distinguished from all other samples, but there is no apparent substructure to the DOM samples and there were insufficient samples to perform a separate PCA of the DOM samples alone.

\subsection{TGA Budget}

The TGA traces can now be apportioned through equation (4) given that the organic matter entering the ecosystem is fixed as primary productivity into biomass. The TGA trace of primary productivity is shown in Figure 8. The TGA trace for litter that is produced from this biomass is difficult to distinguish from the curve for biomass (Figure $3 \mathrm{~b}$ ) and so subsequent calculations were performed using the TGA trace for the litter weighted by a factor of 1 (Figure 8). From the produced litter we can subtract the trace of the deepest measured peat (95-100 cm depth-residual peat; Figure 8) weighted by a factor of 0.22 (the proportion of residual $C$ in equation (4)) to give the TGA trace of what has been lost in the processing of the produced litter, except for that this organic matter is also lost as POM and DOM. Therefore, adding the appropriate proportion of POM and DOM (weighted by 0.09 and 0.26 , respectively; equation (4)) gives the total organic matter that could be accounted for in the solids that could be sampled from the study site. Therefore, by knowing the trace of the inputs (biomass and litter) and the outputs of the organic matter (residual peat, POM and DOM) then, by subtraction, the trace of the organic matter that has been lost from the ecosystem to the atmosphere can be calculated-henceforward referred to as the "lost composition" (Figure 8). Comparing the traces in Figure 8 with Figure 3 suggest that what has been lost is a combination of protein and cellulose. The calculated traces can now be included in the principal component analysis with the other samples and standards.

\begin{tabular}{|c|c|c|c|c|c|c|c|c|c|c|c|c|}
\hline Carbon Pool/Type & $\mathrm{C}_{\mathrm{ox}}$ & OR & $\begin{array}{l}\text { Degree of } \\
\text { Unsaturation } \\
(\Omega)\end{array}$ & $\begin{array}{l}\text { Median } \\
\text { Stoichiometry }\end{array}$ & C-alkyl & N-alkyl & O-alkyl & O2-alkyl & Aromatic & Phenolic & Aldehyde & Carbonyl \\
\hline DOM & 0.40 & 0.92 & 2.42 & $\mathrm{C}_{31} \mathrm{H}_{38} \mathrm{NO}_{24}$ & 14.6 & 8.8 & 11.8 & 10.9 & 12.4 & 9.6 & 7.3 & 23.1 \\
\hline POM & -0.21 & 1.09 & 1.76 & $\mathrm{C}_{22} \mathrm{H}_{35} \mathrm{NO}_{14}$ & 17.0 & 11.8 & 37.9 & 14.6 & 5.9 & 4.0 & 0.5 & 8.2 \\
\hline $\begin{array}{l}\text { Aboveground } \\
\text { biomass }\end{array}$ & -0.26 & 1.08 & 1.98 & $\mathrm{C}_{57} \mathrm{H}_{86} \mathrm{NO}_{35}$ & 13.4 & 8.2 & 37.5 & 16.2 & 8.0 & 7.6 & 1.4 & 7.7 \\
\hline $\begin{array}{l}\text { Belowground } \\
\text { biomass }\end{array}$ & -0.25 & 1.08 & 2.12 & $\mathrm{C}_{49} \mathrm{H}_{73} \mathrm{NO}_{29}$ & 14.3 & 11.6 & 32.8 & 16.1 & 8.1 & 7.7 & 1.9 & 7.5 \\
\hline Grass \& sedge & -0.19 & 1.07 & 1.95 & $\mathrm{C}_{33} \mathrm{H}_{52} \mathrm{NO}_{21}$ & 10.4 & 14.1 & 37.8 & 17.2 & 5.2 & 5.7 & 0.9 & 8.7 \\
\hline Mosses & -0.19 & 1.06 & 1.92 & $\mathrm{C}_{95} \mathrm{H}_{145} \mathrm{NO}_{56}$ & 8.8 & 11.6 & 42.0 & 15.6 & 8.1 & 5.9 & 1.5 & 6.4 \\
\hline Calluna & -0.32 & 1.09 & 2.03 & $\mathrm{C}_{55} \mathrm{H}_{86} \mathrm{NO}_{46}$ & 11.2 & 14.5 & 36.2 & 17.3 & 5.6 & 7.3 & 0.2 & 7.8 \\
\hline Litter & -0.05 & 1.05 & 2.30 & $\mathrm{C}_{25} \mathrm{H}_{35} \mathrm{NO}_{15}$ & 16.2 & 11.6 & 30.4 & 15.3 & 9.0 & 7.5 & 1.7 & 8.9 \\
\hline Peat soil & -0.15 & 1.06 & 2.20 & $\mathrm{C}_{43} \mathrm{H}_{62} \mathrm{NO}_{26}$ & 34.2 & 11.7 & 13.7 & 7.3 & 9.8 & 7.2 & 3.8 & 10.2 \\
\hline Lignin & -0.43 & 1.12 & 3.14 & $\mathrm{C}_{87} \mathrm{H}_{103} \mathrm{NO}_{31}$ & 7.0 & 28.5 & 6.2 & 13.0 & 19.1 & 23.7 & 0.8 & 1.8 \\
\hline Cellulose & 0.05 & 0.99 & 1.11 & $\mathrm{CH}_{2} \mathrm{O}$ & 30.2 & 12.8 & 40.4 & 13.6 & 1.2 & 0.5 & 0.8 & 0.5 \\
\hline Humic acid & 0.19 & 0.97 & 2.18 & $\mathrm{C}_{49} \mathrm{H}_{60} \mathrm{NO}_{33}$ & 26.0 & 9.5 & 3.1 & 6.8 & 25.9 & 10.5 & 3.0 & 15.1 \\
\hline Protein & 0.18 & 0.96 & 3.63 & $\mathrm{C}_{5} \mathrm{H}_{5} \mathrm{NO}$ & 27.5 & 19.7 & 10.9 & 2.4 & 8.6 & 2.3 & 0.9 & 27.6 \\
\hline
\end{tabular}

\footnotetext{
${ }^{a}$ Median stoichiometry is expressed relative to nitrogen content except for cellulose which expressed relative to carbon.
} 
Table 3. Coefficients of the Significant Multiple Regressions on the Range of Compositional Parameters Measured Across the Range of Organic Matter Types and Standards Used Within This Study

Upper End of the Temperature Range $\left({ }^{\circ} \mathrm{C}\right)$

\begin{tabular}{|c|c|c|c|c|c|c|c|c|c|c|c|c|c|}
\hline Parameter & 200 & 250 & 300 & 350 & 400 & 450 & 500 & 550 & 600 & 650 & $\operatorname{Max}\left({ }^{\circ} \mathrm{C}\right)$ & Const. & $R^{2}$ \\
\hline $\mathrm{C}_{\mathrm{ox}}$ & & 0.054 & & & 0.011 & & & & & 0.11 & & -0.87 & 0.72 \\
\hline $\mathrm{C} / \mathrm{N}$ & 2.8 & & & 0.7 & 2.2 & 2.6 & & & & & & -54 & 0.54 \\
\hline $\mathrm{H} / \mathrm{C}$ & & -0.038 & & & & -0.023 & & & & & & 1.9 & 0.37 \\
\hline \multicolumn{14}{|l|}{ C-alkyl } \\
\hline N-alkyl & & & & & & & & & & & 0.04 & -0.9 & 0.18 \\
\hline O-alkyl & & & & 1.4 & & -1.7 & & & & & & 6 & 0.64 \\
\hline $\mathrm{O}_{2}$ - alkyl & & & & & & & -0.9 & & & & & 18 & 0.33 \\
\hline Aromatic & & & & -0.48 & & 1.03 & & & & & & 10 & 0.73 \\
\hline Phenolic & & & & -0.60 & -0.10 & 1.5 & -1.7 & & & & & 20 & 0.74 \\
\hline Aldehyde & 0.7 & & & & & & & & & & & 0.4 & 0.44 \\
\hline Carbonyl & 1.0 & 1.0 & & & & & & & & & & 3 & 0.59 \\
\hline
\end{tabular}

When the PCA is performed again but now including the traces calculated for the compositions lost from the ecosystem, it can be seen that the lost composition plots very close to the cellulose composition (Figure 9). The lost composition can be viewed as being largely cellulose but with some component of either lignin or humic acid. If viewed as a mixing between the studied standards, then the lost composition is either $97 \%$ cellulose and $3 \%$ humic acid or $92 \%$ cellulose and $8 \%$ lignin or a combination of these two end-member mixtures (e.g., 95\% cellulose, $2 \%$ humic acid, and 3\% lignin).

Alternatively, the PCA could be used to give the cellulose, lignin, and protein composition of the aboveground biomass, litter, deep peat, POM, and DOM. Given the compositions of the primary productivity, POM, DOM, and residual peat, then the lost composition can be calculated using equation (4) (Table 6). In this case the lost composition would be Cell ${ }_{40} \mathrm{Lig}_{5} \mathrm{Pro}_{0}$ per $100 \mathrm{~g} \mathrm{C}$ of primary productivity, once again confirming the result found above that cellulose is preferentially lost when organic matter is transferred into and through a peat soil. Furthermore, the analysis in Table 6 shows that POM is predominantly from the residual peat (i.e., peat soil from between 95 and $100 \mathrm{~cm}$ depth). The DOM composition is predominantly from lignin and not from cellulose and has compositions similar to protein.

\section{Discussion}

The comparison of the TGA trace to other measures of the composition shows that the interpretation of the trace in terms of elemental or functional group composition would be difficult because the mass loss for organic matter is concentrated into the region between 300 to $500^{\circ} \mathrm{C}$. However, DOM did have a lower thermal stability than other organic matter fractions studied, and the DOM has a more oxidized nature than the other types of organic matter studied. Plante et al. [2011] and Dorodnikov et al. [2007] have both tried to correlate thermal stability indices derived from TGA with measures of biological turnover of the same soil organic matter. Dell'Abte et al. [2002] associated the "first exothermic region" (300-350 ${ }^{\circ} \mathrm{C}$ ) with the burning of carbohydrates and aliphatic

Table 4. The Loadings on the Principal Components

\begin{tabular}{lcccc} 
Variable & PC1 & PC2 & PC3 & PC4 \\
\hline 200 & 0.36 & 0.10 & 0.00 & 0.39 \\
250 & 0.36 & -0.28 & 0.01 & 0.32 \\
300 & -0.05 & -0.51 & -0.57 & -0.04 \\
350 & -0.39 & -0.08 & -0.19 & -0.26 \\
400 & --0.30 & 0.15 & 0.57 & 0.14 \\
450 & -0.06 & 0.58 & -0.44 & 0.21 \\
500 & 0.29 & 0.49 & -0.26 & -0.10 \\
550 & 0.29 & 0.08 & 0.20 & -0.42 \\
600 & 0.38 & -0.04 & 0.09 & -0.42 \\
650 & 0.39 & -0.11 & 0.03 & -0.18 \\
Max ${ }^{\circ} \mathrm{C}$ & -0.15 & 0.18 & -0.08 & -0.48 \\
\hline
\end{tabular}
compounds, while the "second exothermic region" $\left(400-450^{\circ} \mathrm{C}\right)$ was attributed with the oxidation of aromatic compounds. Table 3 does provide some evidence that losses in region 400 to $450^{\circ} \mathrm{C}$ were positively correlated with the proportion of aromatic and phenolic groups; for example, approximately $30 \%$ of lignin mass was lost in the region 400 to $450^{\circ} \mathrm{C}$ (Figure $3 \mathrm{a}$ ), but there was also positive correlation in this region with the C:N ratio. Further, this study 


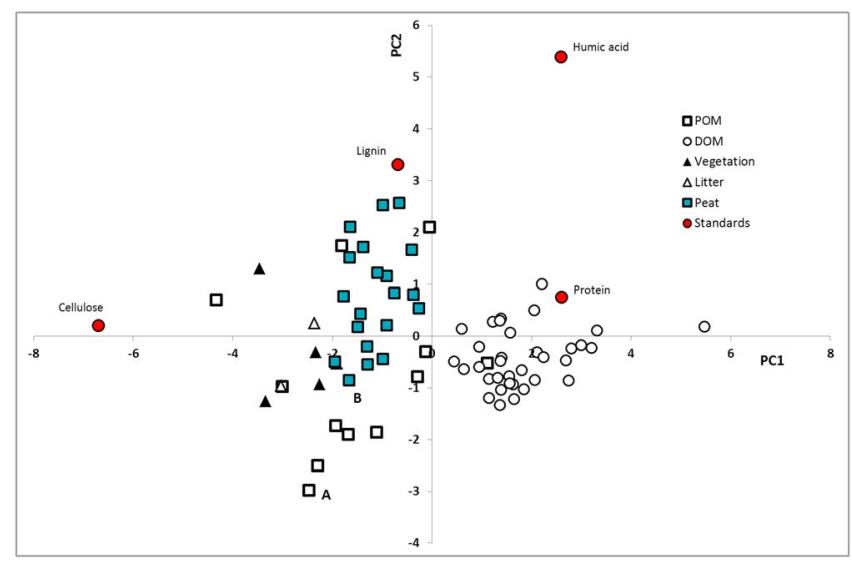

Figure 7. The comparison of $\mathrm{PC1}$ and $\mathrm{PC2}$ for all sample types. found no correlation between C-alkyl groups or O-alkyl groups in the 300 to $350^{\circ} \mathrm{C}$ region.

If it is difficult to interpret the TGA trace in terms of elemental or functional composition, it does give clear patterns in terms of whole composition when interpreted using a multivariate PCA approach. The principal component analysis of the TGA data allows a coherent interpretation of the organic matter budget of a peat ecosystem. Primary productivity sequesters $\mathrm{CO}_{2}$ from the atmosphere which forms biomass as lignin and polysaccharides (here referred to as

cellulose). The primary productivity forms litter and exudates which becomes humified into peat soil. The humification process in this ecosystem sees the loss of $78 \%$ of the primary productivity, but preferentially this loss is of cellulose with $100 \%$ of the $C$ sequestered into the aboveground biomass as cellulose lost by $100 \mathrm{~cm}$ depth but only $54 \%$ of the $C$ sequestered in the aboveground biomass as lignin has been lost.

The loss of carbon can be as any combination of $\mathrm{CO}_{2}, \mathrm{CH}_{4}, \mathrm{DOM}$, or POM. The POM composition shows that it is dominantly sourced from the erosion of peat soil and wash off of vegetation except for the POM of composition A (Figure 7). The DOM composition shows that it is predominantly derived from the humification (or degradation) of lignin but not cellulose. Worrall et al. [2016a] studied the $C_{\text {ox }}$ values of DOM in the context of this field site and suggested that DOM was an intermediary in the complete oxidation of organic matter to $\mathrm{CO}_{2}$. However, this study would separate the process responsible for the majority of the $\mathrm{CO}_{2}$ production (oxidation of carbohydrates such as cellulose) from the process producing the majority of the DOM (lignin metabolism). A number of studies have also observed the preferential loss of polysaccharides over lignin in peat soils [Bracewell et al., 1980; Benner et al., 1984; Van der Heijden and Boon, 1994; Biester et al., 2014]. Equation (4) can now be re-written to account for the changes in polysaccharide, lignin, and protein:

$$
\begin{aligned}
100\left[0.50 C_{\text {cell }}+0.46 C_{\text {lig }}+0.04 C_{\text {pro }}\right]_{\text {PP }}= & 45\left[0.89 C_{\text {cell }}+0.11 C_{\text {lig }}\right]_{R+C H 4+\text { dissCO2 }} \\
& +26\left[0.19 C_{\text {cell }}+0.81 C_{\text {lig }}\right]_{\text {DOC }}+9\left[0.93 C_{\text {lig }}+0.06 C_{\text {pro }}\right]_{\text {POC }} \\
& +22\left[0.94 C_{\text {lig }}+0.06 C_{\text {pro }}\right]_{\text {RES }}
\end{aligned}
$$

where $C_{x}$ indicates carbon from biopolymer $x$, with cell representing as cellulose (polysaccharide), lig as lignin, and pro as protein; with other terms as defined for equation (4). Equation (5) can be represented schematically (Figure 10), and this would imply that protein survives the transition through the peat profile; however, it may simply be that this represents the residual organic $\mathrm{N}$ components or that a microbial population is present in the deep peat which has a protein content and that original plant proteins were readily transformed.

Table 5. Composition of Biomass and Litter Components as Calculated TGA Trace

\begin{tabular}{lc} 
Organic Matter Reservoir & Composition \\
\hline Calluna & Cell $_{36} \mathrm{Lig}_{64} \mathrm{Pro}_{0}$ \\
Sedges/grass & $\mathrm{Cell}_{74} \mathrm{Lig}_{23} \mathrm{PrO}_{3}$ \\
Mosses & $\mathrm{Cell}_{61} \mathrm{Lig}_{24} \mathrm{Pro}_{15}$ \\
Aboveground biomass & $\mathrm{Cell}_{45} \mathrm{Lig}_{52} \mathrm{PrO}_{3}$ \\
Belowground biomass & $\mathrm{Cell}_{53} \mathrm{Lig}_{15} \mathrm{PrO}_{3}$ \\
Litter & $\mathrm{Cell}_{54} \mathrm{Lig}_{19} \mathrm{Pro}_{26}$ \\
Primary productivity & Cell $_{50} \mathrm{Lig}_{46} \mathrm{PrO}_{4}$ \\
\hline
\end{tabular}

The lost composition has important implications for the oxidation state of the peatland. As noted above, OR can be more than a property of a carbon flux or reservoir and can be a property of an ecosystem: the oxidation state of ecosystems can be described by $\mathrm{C}_{\mathrm{ox}}$ which in turn is linearly related to the oxidative ratio of that ecosystem. The value of OR 


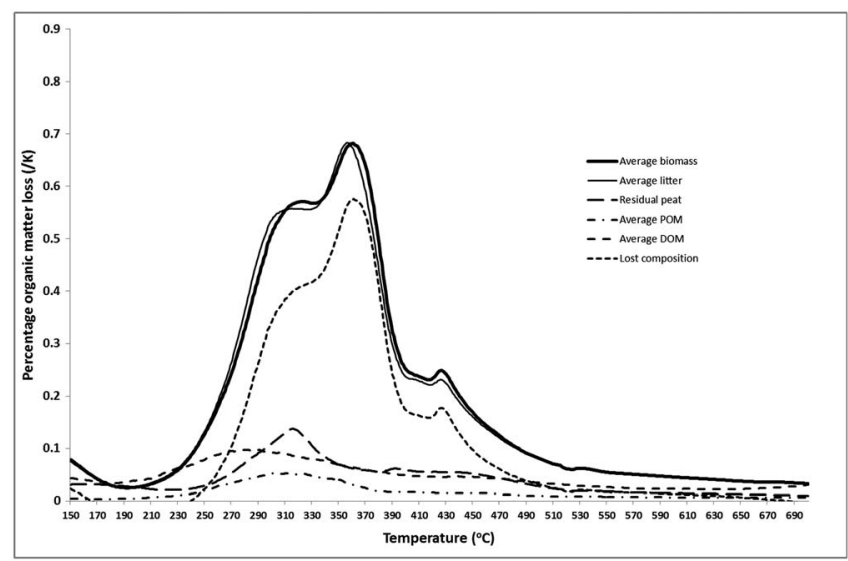

Figure 8. The comparison of the average TGA traces weighted according to their $\mathrm{C}$ flux as per equation (1). has until recently been assumed to be 1.1 [Keeling et al., 1996; Battle et al., 2000; Prentice et al., 2001; Langenfelds et al., 1999; Steinbach et al., 2011; IPCC, 2013] although Keeling and Shertz [1992] used a lower value of 1.05, and Keeling and Manning [2014] have suggested that any attempt to update this value as likely to have only a minimal impact. IPCC [2013] do only use one value of OR for the globe and that value was based upon one value from a single study of the Biosphere 2 experiment [Severinghaus, 1995] that did not set out to measure an OR value applicable to the global terrestrial biosphere.

As an alternative to the assumed value of OR as 1.1, Worrall et al. [2013] compiled elemental analysis from the literature for whole soil and vegetation data from across the globe to provide a flux-weighted estimate of global OR and found a value of $1.03 \pm 0.03$ and argued that the present value used by the Intergovernmental Panel on Climate Change (IPCC) represents the 97th percentile of observed values. Indeed, other studies have confirmed that OR should and does vary in time [Randerson et al., 2006] and between environmental reservoirs [Hockaday et al., 2015]. This approach has been updated to consider the different organic matter pools and reservoirs [Clay and Worrall, 2015a, 2015b] and the speciation of the fluxes from the ecosystem [Worrall et al., 2016a]. Indeed, Worrall et al. [2016a] considered the ecosystem in this study and the flux- and speciation-weighted ecosystem OR was 1.04. However, measurements of OR based upon atmospheric measurements have tended to find even lower values of ecosystem OR than suggested even by Worrall et al. [2016a] with Ishidoya et al. [2013] suggesting a value of 0.86 and van der Laan et al. [2014] a value of 0.89 . For terrestrial litter bag experiments (where oxygen would not be limiting) have shown that organic matter remaining after decomposition is more reduced than the initial biomass [Baldock et al., 2004] because carbohydrates and polysaccharides (oxidized biomolecules) are most readily removed in the initial stages of decomposition.

The present studies of OR [e.g., Clay and Worrall, 2015a] have been largely based upon measurements of the organic matter left behind after oxidation (e.g., soil organic matter), or in some cases have taken into account the organic matter that is in transition (e.g., DOM) into longer-term carbon stores. It is impossible to directly sample the organic matter that had already reacted and turned over to the atmosphere as this component has been lost from the ecosystem although studies based on atmospheric measurement [Ishidoya et al.,

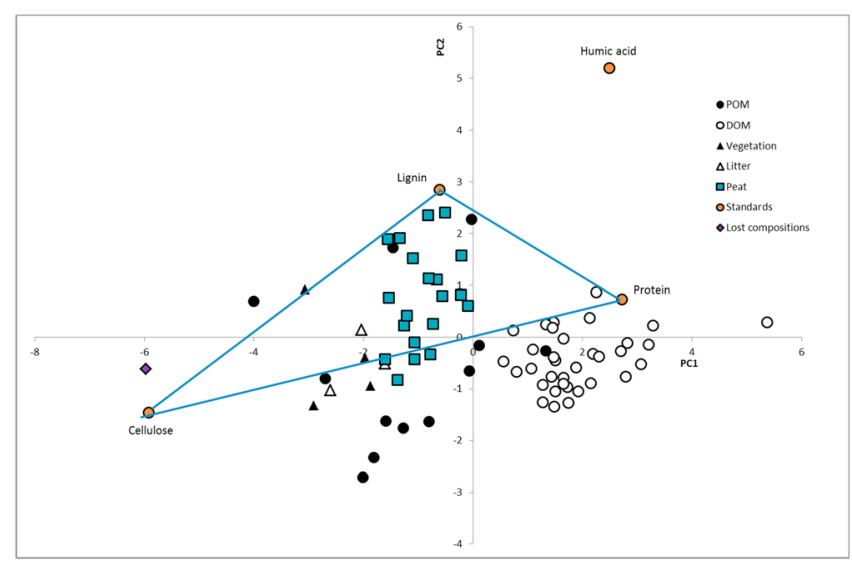

Figure 9. The comparison of PC1 and PC2 for all sample types including the projected lost composition.
2013; van der Laan et al., 2014] provide an alternative perspective. The carbon-flux-weighted TGA traces demonstrate that the composition that is missing (removed to the atmosphere) is dominated by cellulosic compounds. Since the composition starts as a ligno-cellulose copolymer and is observed to evolve toward a lignin-like composition, then it must be a cellulosic composition that is lost. In this case, however, erosion of particles and flushing of dissolved organic matter mean that some organic matter is lost from the ecosystem not as gases. Therefore, the OR of the ecosystem, the OR 
Table 6. Composition of the Organic Matter Reservoirs and Fluxes Based Upon TGA Trace and as Weighted via Equation (1)

\begin{tabular}{llc} 
Organic Matter Reservoir & Proportion & Mass \\
\hline Primary productivity & $\mathrm{Cell}_{50} \mathrm{Lig}_{46} \mathrm{PrO}_{4}$ & 612 \\
Primary productivity/100gC & $\mathrm{Cell}_{50} \mathrm{Lig}_{46} \mathrm{PrO}_{4}$ & 100 \\
Reacted composition & $\mathrm{Cell}_{41} \mathrm{Lig}_{33} \mathrm{PrO}_{3}$ & 78 \\
Lost composition & $\mathrm{Cell}_{40} \mathrm{Lig}_{5} \mathrm{Pro}_{0}$ & 45 \\
Fluvial flux composition & $\mathrm{Cell}_{2} \mathrm{Lig}_{28} \mathrm{Pro}_{3}$ & 33 \\
POM composition & $\mathrm{Cell}_{0} \mathrm{Lig}_{8} \mathrm{PrO}_{1}$ & 9 \\
DOM composition & $\mathrm{Cell}_{2} \mathrm{Lig}_{21} \mathrm{Pro}_{3}$ & 26 \\
Residual peat & $\mathrm{Cell}_{0} \mathrm{Lig}_{21} \mathrm{Pro}_{1}$ & 22 \\
\hline
\end{tabular}

$$
\begin{gathered}
\mathrm{OR}_{\text {ecosystem }}=f_{\text {lost }} \mathrm{OR}_{\text {lost }}+\delta_{\mathrm{POM}} f_{\mathrm{POM}} \mathrm{OR}_{\mathrm{POM}}+\delta_{\mathrm{DOM}} f_{\mathrm{DOM}} \mathrm{OR}_{\mathrm{DOM}} \\
1=f_{\text {lost }}+\delta_{\mathrm{POM}} f_{\mathrm{POM}}+\delta_{\mathrm{DOM}} f_{\mathrm{DOM}}
\end{gathered}
$$

where $\mathrm{OR}_{x}$ is the oxidative ratio of $x$ ( $x$ is lost composition, $\mathrm{POM}$ or DOM), $f_{x}$ is the fraction of the flux from the ecosystem that is $x$ ( $x$ is lost composition, POM or DOM), and $\delta_{x}$ is the fraction of the flux of $x$ from the ecosystem that atmospherically active with $x$ as POM or DOM. The OR $\mathrm{R}_{\text {lost }}$ comes from the linear combination of the OR of cellulose, humic acid, or lignin; the $\mathrm{OR}_{\mathrm{POM}}$ and $\mathrm{OR}_{\mathrm{DOM}}$ were taken as the average and range of that measured above, 1.08 (0.93 to 1.22) and 0.91 (0.86 to 0.96 ), respectively. The fractions of the POM and DOM that are lost to atmosphere have been measured in this catchment [Moody et al., 2013] as 0.76 for DOM and

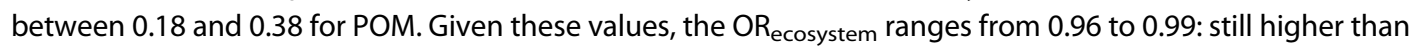
measured or observed by Ishidoya et al. [2013] and van der Laan et al. [2014] but distinctly lower than the value of 1.04 previously proposed for this ecosystem by Worrall et al. [2016a].

Battle et al. [2000] have proposed the following equations:

$$
\begin{gathered}
f_{\text {land }}=-\frac{\mathrm{CS}}{\mathrm{OR}_{\text {terra }}^{\text {global }}} f_{\text {fuel }}+\frac{1}{k_{1} k_{2} \mathrm{OR}_{\text {terra }}^{\text {global }}} \frac{d\left(\frac{\mathrm{O}_{2}}{\mathrm{~N}_{2}}\right)}{d t} \\
f_{\text {ocean }}=-\frac{1}{k_{1}} \frac{d\left(\mathrm{CO}_{2}\right)}{d t}-\frac{1}{k_{1} k_{2} \mathrm{OR}_{\text {terra }}^{\text {global }}} \frac{d\left(\frac{\mathrm{O}_{2}}{\mathrm{~N}_{2}}\right)}{d t}-\frac{\mathrm{OR}_{\text {terra }}^{\text {global }}-\mathrm{CS}}{\mathrm{OR}_{\text {terra }}^{\text {global }}} f_{\text {fuel }}-f_{\text {cement }}
\end{gathered}
$$

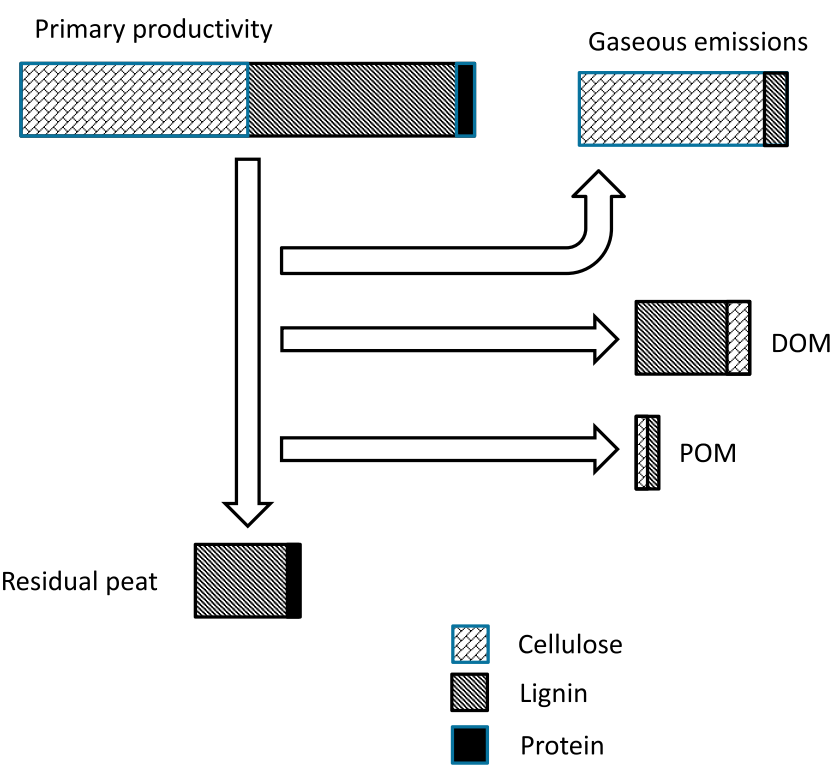

Figure 10. Schematic representation of equation (2) scaled for the size of its carbon flux and composition as predicted from equation (1) and from Figure 8. where $f_{x}$ is the annual flux of $\mathrm{CO}_{2}$ (Gt $\mathrm{C} / \mathrm{yr}$ ) with $x$ as the land, ocean, fuel, or cement; $\left(\mathrm{O}_{2} / \mathrm{N}_{2}\right)$ is the molar ratio of atmospheric $\mathrm{O}_{2}$ and $\mathrm{N}_{2} ; \mathrm{CS}$ is the combustion stoichiometry $(1.43$ [Battle et al., 2000]); OR $\mathrm{O}_{\text {terra }}^{\text {global }}$ is the oxidative ratio of the global terrestrial biosphere; and constants $k_{1}$ and $k_{2}$ are converted ppm in the atmosphere to per meg (which is ppm on a molecular basis for oxygen alone) -the values are 0.471 and 4.776 , respectively. Applying the previously used value of $O R\left(O R_{\text {global }}^{\text {terra }}=1.1\right)$ and leaving all other terms equal in equations (8) and (9) then $f_{\text {land }}=1.40 \mathrm{Gt} \quad \mathrm{C} / \mathrm{yr}$ and $f_{\text {ocean }}=2.11 \mathrm{Gt} \mathrm{C/yr}$. Taking the estimate of $\mathrm{OR}_{\text {global }}^{\text {terra }}$ value of 1.04 from Worrall et al. [2016a] then $f_{\text {land }}=1.47 \mathrm{Gt} \quad \mathrm{C} / \mathrm{yr}$ and $f_{\text {oceans }}=2.0 \mathrm{Gt} \mathrm{C} / \mathrm{yr}$. Given the 
estimates derived in this study (based upon an $\mathrm{OR}=0.975$-the median of the range estimated from this study of 0.96 to 0.99 ) then $f_{\text {land }}=1.60 \mathrm{Gt} \mathrm{C} / \mathrm{yr}$ and $\mathrm{f}_{\text {oceans }}=1.88 \mathrm{Gt} \mathrm{C} / \mathrm{yr}$.

\section{Conclusions}

The study has shown that thermogravimetric analysis (TGA) can distinguish between the organic matter fluxes and reservoirs across a peatland ecosystem. The comparison of the TGA in the context of a known carbon budget for the site shows that while primary productivity sequesters carbon from the atmosphere which is transformed into lignin and polysaccharides, it is the polysaccharides that are preferentially lost through degradation and the residual peat at $1 \mathrm{~m}$ depth is predominantly lignin-like. The loss of particulate organic matter (POM) is shown to be from erosion of peat soil and vegetation, while the dissolved organic matter (DOM) appears to be the degradation product of lignin with only a small contribution from polysaccharides. Of $100 \mathrm{~g}$ of $C$ taken up as primary productivity (50\% polysaccharide-C; $46 \%$ lignin- $C$ ) $22 \mathrm{~g}$ of $C$ would be left as residual peat at $1 \mathrm{~m}$ depth of which $95 \%$ was lignin-C. Of the $100 \mathrm{~g}$ of $C$ taken up as primary productivity $26 \mathrm{~g}$ of $\mathrm{C}$ was lost via DOM flux of which $81 \%$ was lignin-C; $9 \mathrm{~g}$ of $\mathrm{C}$ was lost via POM flux which was $89 \%$ lignin-C. Therefore, of the $100 \mathrm{~g}$ of $\mathrm{C}$ taken up as primary productivity, $46 \mathrm{~g}$ would be lost as $\mathrm{CO}_{2}$ and $\mathrm{CH}_{4}$ fluxes of which between 89 and $95 \%$ was polysaccharide-C. The composition lost from the peat via all pathways would then be between 92 and $95 \%$ polysaccharide- $\mathrm{C}$ and up to $8 \%$ lignin-C. The dominate role in $\mathrm{CO}_{2}$ release for polysaccharides means that the oxidative ratio (OR) of the ecosystem is between 0.96 and 0.99 and not 1.04 as previously thought and if true for other environments would have radical consequences for the value of OR (1.1) as used by the IPCC.

\section{Acknowledgments}

The authors are grateful to the Environmental Change Network for the data from the Moor House site. The data used in this study are available from the corresponding authors (fred.worrall@durham.ac.uk) or from the Environmental Change Network (http://www.ecn.asc.uk).

\section{References}

Artz, R. R. E., S. J. Chapman, A. H. J. Robertson, J. M. Potts, F. Laggoun-Defarge, S. Gogo, L. Comont, J.-R. Disnar, and A.-J. Francez (2008), FTIR spectroscopy can be used as a screening tool for organic matter quality in regenerating cutover peatlands, Soil Biol. Biochem., 40, 515-527.

Baldock, J. A., C. A. Masiello, Y. Gelinas, and J. I. Hedges (2004), Cycling and composition of organic matter in terrestrial and marine ecosystems, Mar. Chem., 92, 39-64.

Battle, M., M. I. Bender, P. P. Tans, J. W. C. White, J. T. Ellis, T. Conway, and R. J. Francey (2000), Global carbon sinks and their variability inferred from atmospheric O-2 and delta C-13, Science, 287(5462), 2467-2470.

Benner, R., A. F. Mac Cubbin, and R. E. Hodson (1984), Anaerobic biodegradation of the lignin and polysaccharide components of lignocellulose and synthetic lignin by sediment microflora, Appl. Environ. Microbiol., 47(3), 998-1004.

Biester, H., K. H. Knorr, J. Schellekens, A. Basler, and Y.-M. Hermanns (2014), Comparison of different methods to determine the degree of peat decomposition in peat bogs, Biogeosciences, 11, 2691-2707.

Billett, M. F., S. M. Palmer, D. Hope, C. Deacon, R. Storeton-West, K. J. Hargreaves, C. Flechard, and D. Fowler (2004), Linking land-atmospherestream carbon fluxes in a lowland peatland system, Global Biogeochem. Cycles, 18, GB1024, doi:10.1029/2003GB002058.

Blackford, J. J., and F. M. Chambers (1993), Determining the degree of peat decomposition for peat-based palaeoclimatic studies, Int. Peat J., $5,7-24$.

Bracewell, J. M., G. W. Robertson, and B. L. Williams (1980), Pyrolysis mass spectroscopy studies of humification in a peat and a peaty podzol, J. Anal. Appl. Pyrolysis, 2, 53-62.

Buurman, P., K. G. J. Nierop, X. Pontevedra-Pombal, and A. Martinez-Cortizas (2006), Molecular chemistry for pyrolysis-GC/MS of selected samples of the penido veilo peat deposit NW Spain, Peatlands Evol. Rec. Environ. Clim. Changes, 217-240.

Carrie, J., H. Sanei, and G. Stern (2012), Standardisation of rock-eval pyrolysis for the analysis of recent sediments and soils, Org. Geochem., 46, 38-53.

Chadwick, O. A., C. A. Masiello, J. Baldock, R. Smernik, and J. Randerson (2004), The oxidation state of soil organic carbon: A new proxy for carbon storage mechanisms and land use change, Kearney Foundation of Soil Science: Soil Carbon and California's Terrestrial Ecosystems Final Report: 2002020, 1/1/2003-12/31/2004.

Chatfield, C., and A. J. Collins (1980), Introduction to Multivariate Analysis, Chapman and Hall, London.

Clay, G. D., and F. Worrall (2015a), Oxidative ratio (OR) of Southern African soils and vegetation: Updating the global OR estimate, Catena, 126, 126-133.

Clay, G. D., and F. Worrall (2015b), Estimating the oxidative ratio of UK peats and agricultural soils, Soil Use Manage., 31(1), 77-88.

Clay, G. D., F. Worrall, and R. Rose (2010), Carbon budgets of an upland blanket bog managed by prescribed fire-Evidence for enhanced carbon storage under managed burning, J. Geophys. Res., 115, G04037, doi:10.1029/2010JG001331.

Dell'Abte, M. T., A. Benedetti, A. Trinchera, and C. Dazzi (2002), Humic substances along the profile of two typic Haploxerert, Geoderma, 107, 281-296.

Dell'Abte, M. T., A. Benedetti, and P. C. Brookes (2003), Hyphenated techniques of thermal analysis for characterisation of soil humic substances, J. Sep. Sci., 26, 433-440.

Dorodnikov, M., A. Fangmeier, and Y. Kuzyakov (2007), Thermal stability of soil organic matter pools and their d13C values after C3-C4 vegetation change, Soil Biol. Biochem., 39, 1173-1180.

Evans, M. G., T. P. Burt, J. Holden, and J. K. Adamson (1999), Runoff generation and water table fluctuations in blanket peat: Evidence from UK data spanning the dry summer of 1995, J. Hydrol., 221, 141-160.

Forrest, G. I. (1971), Structure and production of North Pennine blanket bog vegetation, J. Ecol., 59(2), 453-479.

Gallagher, M. E., C. A. Masiello, W. C. Hockaday, J. A. Baldock, S. Snapp, and C. P. McSwiney (2014), Controls on the oxidative ratio of net primary production in agricultural ecosystems, Biogeochemistry, 121(3), 581-591. 
Gregorich, E. G., A. W. Gillespie, M. H. Beare, D. Curtin, H. Snei, and S. F. Yanni (2015), Evaluating biodegradability of soil organic matter by its thermal stability and chemical composition, Soil Biol. Biochem., 91, 182-191.

Gorham, E. (1991), Northern peatlands: Role in the carbon cycle and probable responses to climate warming, Ecol. Appl., 1, $182-195$. Hemond, H. F. (1983), The nitrogen budget of Thoreau's bog, Ecology, 64(1), 99-109.

Hockaday, W. C., M. E. Gallagher, C. A. Masiello, J. A. Baldock, C. M. Iversen, and R. J. Norby (2015), Forest soil carbon oxidation state and oxidative ratio responses to elevated $\mathrm{CO}_{2}$, J. Geophys. Res. Biogeosci., 120, 1797-1811, doi:10.1002/2015JG003010.

Holden, J., and R. Rose (2011), Temperature and surface lapse rate change: A study of the UK's longest upland instrumental record, Int. J. Climatol., 31(6), 907-919.

Houghton, J. T., L. G. Meira-Filho, B. A. Callender, N. Harris, A. Kattenberg, and K. Maskell (1995), Climate Change 1995: The Science of Climate Change, p. 339, Cambridge Univ. Press, Cambridge, U. K.

Intergovernmental Panel on Climate Change (IPCC) (2013), Climate Change 2013: The Physical Science Basis. Contribution of Working Group I to the Fifth Assessment Report of the Intergovernmental Panel on Climate Change, edited by T. F. Stocker et al., Cambridge Univ. Press, Cambridge, U. K., and New York.

Ishidoya, S., S. Murayama, H. Kondo, N. Saigusa, A. Kishimoto-Mo, and S. Yamamoto (2013), Observation of $\mathrm{O}_{2}: \mathrm{CO}_{2}$ exchange ratio for net turbulent fluxes and its application to forest carbon cycles, Ecol. Res., 30(2), 225-234.

Johnson, G. A. L., and K. Dunham (1963), The Geology of Moor House, Nat. Conserv. Council, HMSO, London.

Jones, M. C., D. M. Peteet, and R. Sambrotto (2010), Late-glacial and Holocene $\delta{ }^{15} \mathrm{~N}$ and $\delta{ }^{13} \mathrm{C}$ variation from a Kenai Peninsula, Alaska peatland, Palaeogeogr. Palaeoclimatol. Palaeoecol., 293(1-2), 132-143.

Keeling, R. F., and A. C. Manning (2014), Studies of recent changes in atmospheric $\mathrm{O}_{2}$ content, in Treatise on Geochemistry, 2nd ed., vol. 5-15, edited by H. D. Holland and K. K. Turekian, pp. 385-404, Elsevier, Oxford.

Keeling, R. F., and S. R. Shertz (1992), Seasonal and interannual variations in atmospheric oxygen and implications for the global carbon cycle, Nature, 358, 723-727.

Keeling, R. F., S. C. Piper, and M. Heimann (1996), Global and hemispheric $\mathrm{CO}_{2}$ sinks deduced from changes in atmospheric $\mathrm{O}_{2}$ concentration, Nature, 381, 218-221.

Kuhry, P., and D. H. Vitt (1996), Fossil carbon/nitrogen ratios as a measure of peat decomposition, Ecology, 77, 271-275.

Kristensen, E. (1990), Characterisation of biogenic organic matter by stepwise thermogravimetry (STG), Biogeochemistry, 9, 135-159.

Langenfelds, R. L., R. J. Francey, L. P. Steele, M. Battle, R. F. Keeling, and W. F. Budd (1999), Partitioning of the global fossil $\mathrm{CO}_{2}$ sink using a 19 year trend in atmospheric $\mathrm{O}_{2}$, Geophys. Res. Lett., 26(13), 1897-1900, doi:10.1029/1999GL900446.

LaRowe, D. E., and P. Van Cappellan (2011), Degradation of natural organic matter: a thermodynamic analysis, Geochim. Cosmochim. Acta, 75, 2030-2042.

Le Quere, C., et al. (2016), Global carbon budget 2016, Earth Syst. Sci. Data, 8, 605-649.

Loisel, J., et al. (2014), A database and synthesis of northern peatland soil properties and Holocene carbon and nitrogen accumulation, Holocene, 24(9), 1028-1042.

Loisel, J., S. van Bellen, L. Pelletier, J. Talbot, G. Hugelius, D. Karran, Z. Yu, J. Nichols, and J. Holmquist (2017), Insights and issues with estimating northern peatland carbon stocks and fluxes since the Last Glacial Maximum, Earth Sci. Rev., 165, 59-80.

Lopez-Capel, E., S. P. Sohi, J. L. Gaunt, and D. A. C. Manning (2005), Use of thermogravimetric differential scanning calorimetry to characterise modelable soil organic matter fractions, Soil Sci. Soc. Am. J., 69, 136-140.

Lopez-Capel, E., G. D. Abbott, K. M. Thomas, and D. A. C. Manning (2006), Coupling of thermal analysis with quadrupole mass spectrometry and isotope ratio mass spectrometry for simultaneous determination of evolved gases and their carbon isotopic composition, J. Anal. Appl. Pyrolysis, 75(2), 82-89.

Masiello, C. A., M. E. Gallagher, J. T. Randerson, R. M. Deco, and O. A. Chadwick (2008), Evaluating two experimental approaches for measuring ecosystem carbon oxidation state and oxidative ratio, J. Geophys. Res., 113, G03010, doi:10.1029/2007JG000534.

McClymont, E. L., E. M. Bingham, C. J. Nott, F. M. Chambers, R. D. Pancost, and R. P. Evershed (2011), Pyrolysis-GC-MS as a rapid screening tool for determination of peat-forming plant composition in cores from ombrotrophic peat, Org. Geochem., 42, $1420-1435$.

McDermitt, D. K., and R. S. Loomis (1981), Elemental composition of biomass and its relation to energy content, growth efficiency, and growth yield, Ann. Bot., 48, 275-290.

McMurray, J. E. (2004), Organic Chemistry, 6th ed., Brooks Cole, London.

Moody, C. S., F. Worrall, C. D. Evans, and T. G. Jones (2013), The rate of loss of dissolved organic carbon (DOC) through a catchment, J. Hydrol., 492, 139-150.

Nilsson, M., J. Sagerfors, I. Buffam, H. Laudon, T. Eriksson, A. Grelle, L. Klemedtsson, P. Weslien, and A. Lindroth (2008), Contemporary carbon accumulation in a boreal oligotrophic minerogenic mire-A significant sink after accounting for all C-fluxes, Global Change Biol., 14(10), 2317-2332.

Petrescu, A. M. R., et al. (2015), The uncertain climate footprint of wetlands under human pressure, Proc. Natl. Acad. Sci. U.S.A., 112(5), 4594-4599.

Plante, A. F., M. Pernes, and C. Chenu (2005), Changes in clay associated organic matter quality in a C depletion sequence as measured by differential thermal analysis, Geoderma, 129, 186-199.

Plante, A. F., J. M. Fernandez, and J. Leifeld (2009), Application of thermal analysis techniques in soil science, Geoderma, 153, 1-15.

Plante, A. F., J. M. Fernadez, M. L. Haddix, J. M. Steinweg, and R. T. Conant (2011), Biological, chemical and thermal indices of soil organic matter stability in four grassland soils, Soil Biol. Biochem., 43, 1051-1058.

Prentice, I. C., et al. (2001), The carbon cycle and atmospheric carbon dioxide, in Climate Change 2001, The Scientific Basis, Contributions of Working Group I to the Third Assessment Report of the Intergovernmental Panel on Climate Change, edited by J. T. Houghton et al., Cambridge Univ. Press, Cambridge, U. K.

Randerson, J. T., C. A. Masiello, C. J. Still, T. Rahn, H. Poorter, and C. B. Field (2006), Is carbon within the global terrestrial biosphere becoming more oxidized? Implications for trends in atmospheric $\mathrm{O}_{2}$, Global Change Biol., 12, 260-271.

Richardson, C. J., and P. E. Marshall (1986), Processes controlling movement, storage, and export of phosphorus in a fen peatland, Ecol. Monogr., 56, 279-302.

Roulet, N. T., P. M. LaFleur, P. J. Richards, T. R. Moore, E. R. Humphreys, and J. Bubier (2007), Contemporary carbon balance and late Holocene carbon accumulation in a northern peatland, Global Change Biol., 13, 397-411.

Rowson, J. G., H. S. Gibson, F. Worrall, N. Ostle, T. P. Burt, and J. K. Adamson (2010), The complete carbon budget of a drained peat catchment, Soil Use Manage., 26(3), 261-273.

Rudolph, H., and J. Samlund (1985), Occurrence and metabolism of sphagnum acid in the cell walls of byrophytes, Phytochemistry, 24, 745-749. Rydin, H., and J. K. Jeglum (2013), The Biology of Peatlands, 2nd ed., Oxford Univ. Press, Oxford, U. K. 
Schillereff, D. N., J. F. Boyle, H. Toberman, J. L. Adams, C. L. Bryant, R. C. Chiverell, R. C. Helliwell, P. Keenan, A. Lilly, and E. Tipping (2016), Longterm macronutrient stoichiometry of UK ombrotrophic peatlands, Sci. Total Environ., 572, 1561-1572, doi:10.1016/j.scitotenv.2016.03.180. Severinghaus, J. P. (1995), Studies of the terrestrial $\mathrm{O}_{2}$ and carbon cycles in sand dunes gases and in Biosphere 2, PhD thesis, Columbia Univ. New York.

Steinbach, J., C. Gerbig, C. Rodenbeck, U. Karstens, C. Minejima, and H. Mukai (2011), The $\mathrm{CO}_{2}$ release and oxygen uptake from fossil fuel emission estimate (COFFEE) dataset: Effects from varying oxidative ratios, Atmos. Chem. Phys., 11, 6855-6870.

Sykes, J. M., and A. M. J. Lane (1996), The United Kingdom Environmental Change Network: Protocols for Standard Measurements of Terrestrial Sites, p. 220, Nat. Environ. Res. Council, London.

Turetsky, M. R., S. W. Manning, and R. K. Wieder (2004), Dating recent peat deposits, Wetlands, 24, 324-356.

Van der Heijden, E., and J. J. Boon (1994), A combined pyrolysis mass spectrometric and light microscopic study of peatified Calluna wood isolated from raised bog peat deposits, Org. Geochem., 32(6), 903-919.

van der Laan, S., I. T. van der Laan-Luijkx, C. Roedenbeck, A. Varlagin, I. Shironya, R. E. M. Neubert, M. Ramonet, and H. A. J. Meijer (2014), Atmospheric $\mathrm{CO}_{2}$, delta $\left(\mathrm{O}_{2} / \mathrm{N}_{2}\right)$, APO and oxidative ratios from aircraft flask samples over Fyodorovskoye, Western Russia, Atmos. Environ., 97, 174-181.

Wang, G., K. Bao, X. Yu, H. Zhao, Q. Lin, and X. Lu (2012), Forms and accumulation of soil P in a subalpine peatland of Mt. Changbai in Northeast China, Catena, 92, 22-29.

Wang, M., T. R. Moore, J. Talbot, and J. L. Riley (2015), The stoichiometry of carbon and nutrients in peat formation, Global Biogeochem. Cycles, 29, 113-121, doi:10.1002/2014GB005000.

Worrall, F., M. Reed, J. Warburton, and T. P. Burt (2003), Carbon budget for British upland peat catchment, Sci. Total Environ., 312, 133-146.

Worrall, F., T. P. Burt, J. G. Rowson, J. Warburton, and J. K. Adamson (2009), The multi-annual carbon budget of a peat-covered catchment, Sci. Total Environ., 407(13), 4084-4094.

Worrall, F., G. D. Clay, T. P. Burt, and R. Rose (2012), The multi-annual nitrogen budget of a peat-covered catchment-Changing from sink to source?, Sci. Total Environ., 433, 176-188.

Worrall, F., G. D. Clay, C. A. Masiello, and G. Mynheer (2013), Estimating the oxidative ratio of terrestrial biosphere carbon-Global carbon sinks have been underestimated, Biogeochemistry, 115(1-3), 23-32.

Worrall, F., G. D. Clay, C. S. Moody, T. P. Burt, and R. Rose (2016a), The effective oxidation state of a peatland, J. Geophys. Res. Biogeosci., 121, 145-158, doi:10.1002/2015JG003182.

Worrall, F., G. D. Clay, C. S. Moody, T. P. Burt, and R. Rose (2016b), The total phosphorus budget of a peat-covered catchment, J. Geophys. Res. Biogeosci., 121, 1814-1828, doi:10.1002/2016JG003375.

Yu, Z. C. (2012), Northern peatland carbon stocks and dynamics: a review, Biogeosciences, 9, 4071-4085.

Yu, Z., J. Loisel, D. J. Cahrman, D. Beilman, and P. Camil (2014), Holocene peatland carbon dynamics in the circum-Arctic region: An introduction, Holocene, 24, 1-7.

Zaccone, C., D. Said-Pullicino, G. Gigliotti, and T. M. Miano (2008), Diagenetic trends in the phenlic constituents of Sphagnum-dominated pet and its corresponding humic fraction, Org. Geochem., 39, 830-838. 